\title{
A review of Fiji's Energy Situation: Challenges and Strategies as a Small Island Developing
} State

\author{
Ravita D. Prasad ${ }^{\mathrm{a}, \mathrm{b}, *}$, R. C. Bansal ${ }^{\mathrm{c}}$, Atul Raturi ${ }^{\mathrm{a}}$ \\ ${ }^{a}$ Faculty of Science, Technology and Environment, The University of the South Pacific, Laucala \\ Campus, Suva, Fiji. (*Corresponding Author email: atul.raturi@usp.ac.fj) \\ ${ }^{\mathrm{b}}$ College of Engineering, Science and Technology, Fiji National University, P. O. Box 7222, \\ Nasinu, Fiji. (*Corresponding Author email: ravita.prasad@fnu.ac.fi or \\ prasad_ravita@yahoo.com) \\ ${ }^{c}$ Department of Electrical, Electronic and Computer Engineering, University of Pretoria, South \\ Africa.(email: rcbansal@gmail.com)
}

\begin{abstract}
Fiji is an island country with just over 300 small islands and approximately 853,000 people. It is a small island developing state (SIDS) that is heavily dependent on imported fossil fuel for its energy needs. The paper attempts to determine the past and current energy situation in Fiji, challenges faced and strategizes to overcome these challenges. In 2014, Fiji generated $859 \mathrm{GWh}$ of grid electricity from $259.8 \mathrm{MW}$ of power plants. Here, $45.4 \%$ of grid electricity was produced by hydro, $50.9 \%$ by diesel generators and the remaining by biomass. However, Fiji's transport sector is completely dependent on fossil fuels with fuel import bill equivalent to an average $58 \%$ of export earnings and taking up $21 \%$ of total import bill. The smallness of Fiji and dispersed islands within Fiji group leads to many challenges to have accessible, affordable and sustainable energy supply. These challenges are comprehensively discussed in this paper. Strategies such as increasing private-public partnership in renewable energy projects, changing customer behavior, setting up a credible feed-in tariff structure, developing locally owned business in renewable energy and energy efficiency, setting up of risk mitigation facilities and strengthening institutions supporting energy sector are discussed to overcome or minimize challenges.
\end{abstract}

Keywords: Small Island Developing States, renewable energy, fossil fuels, electricity generation, Fiji, Pacific region.

\section{Contents}

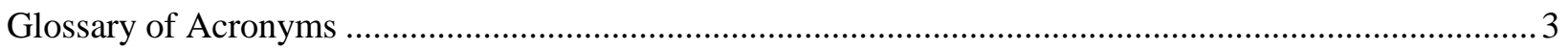

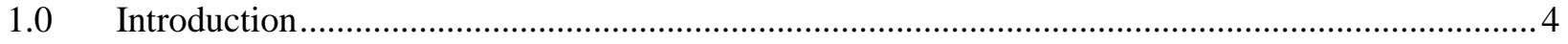

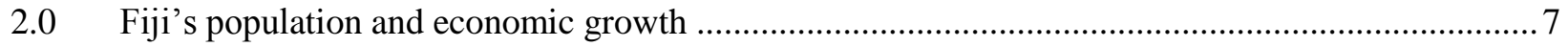

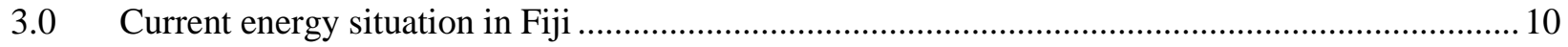

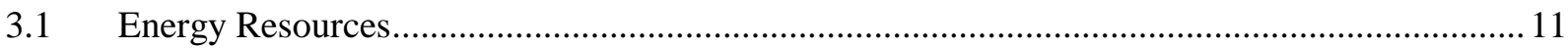




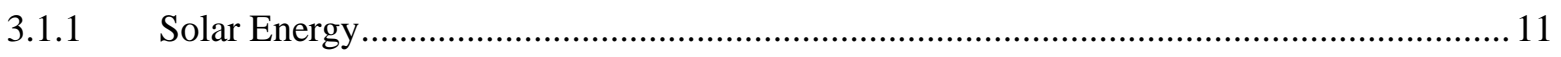

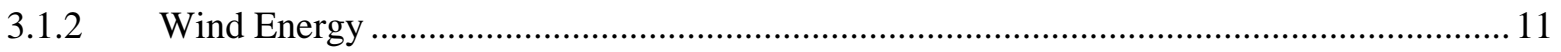

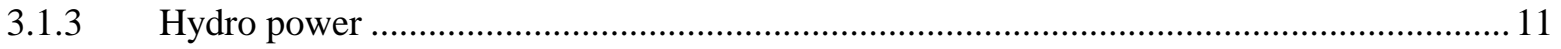

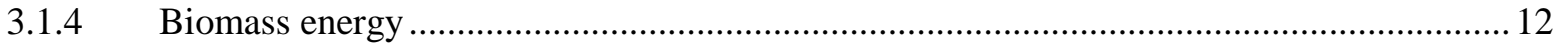

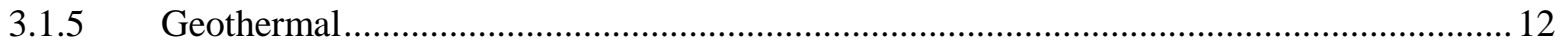

3.2 Grid electricity generation by source and peak demand ........................................................ 12

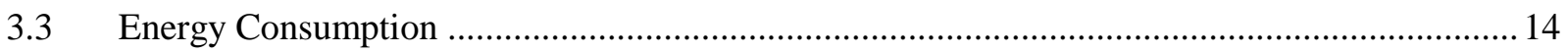

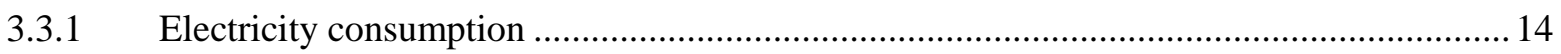

3.3.1.1 Electricity consumption and generation.................................................................... 14

3.3.1.2 Domestic and Non-domestic electricity consumption ................................................ 16

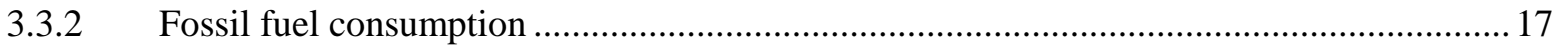

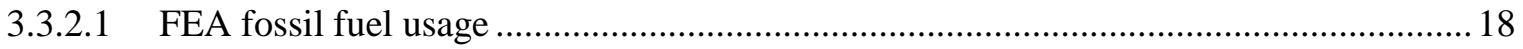

3.3.2.2 Transport and industrial sector fossil fuel usage ......................................................... 19

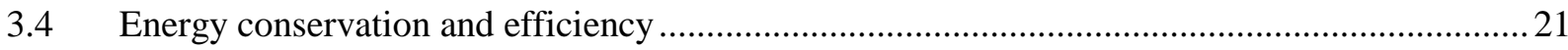

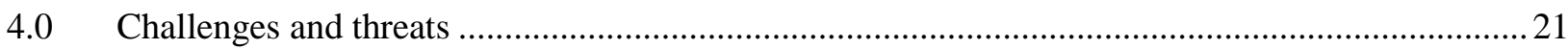

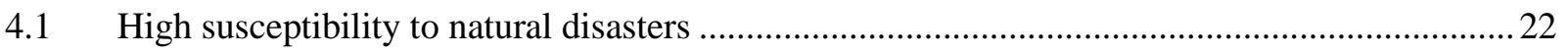

4.2 High ratio of fossil fuel import to total export in Fiji ..............................................................22

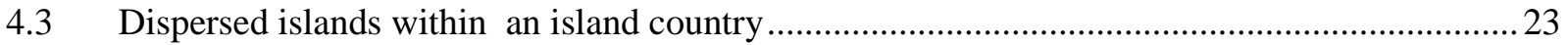

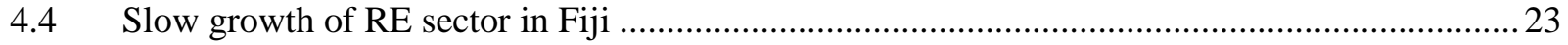

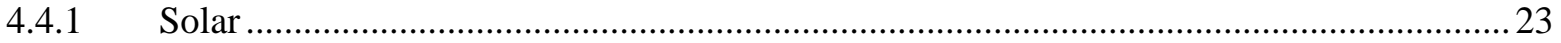

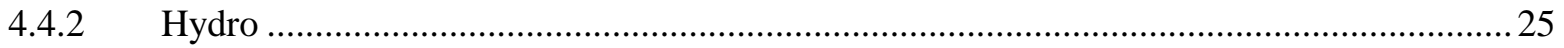

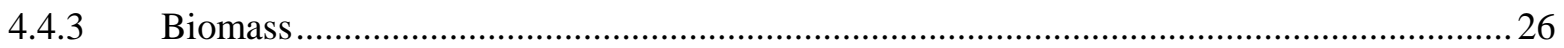

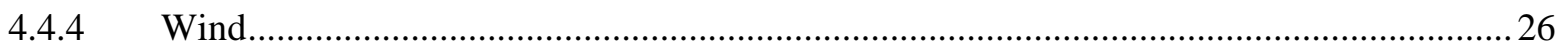

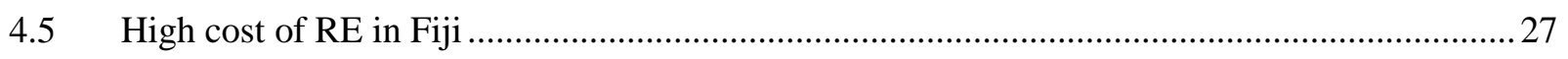

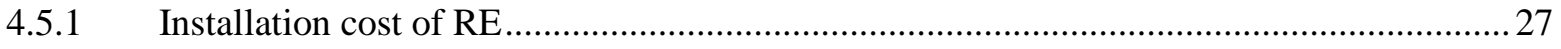

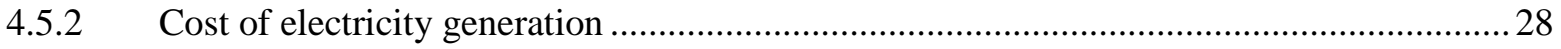

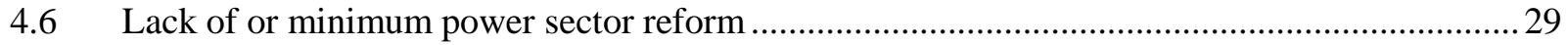

4.7 Higher Energy Output Ratio or Energy Intensity .................................................................... 31

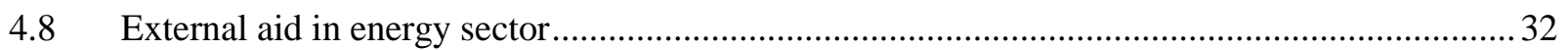

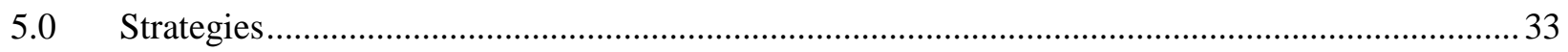

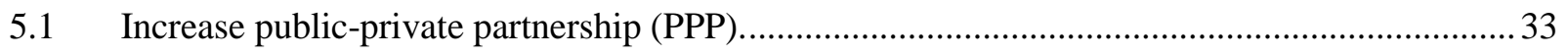

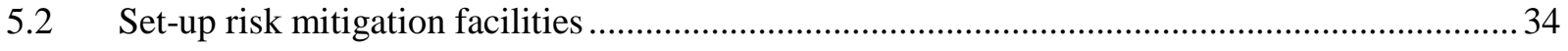

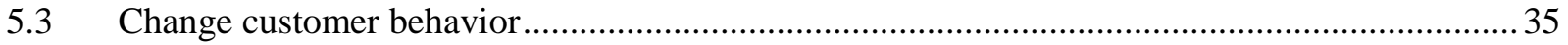




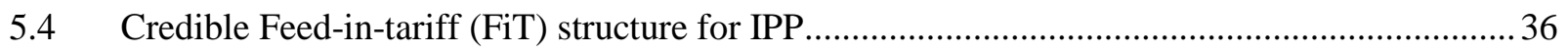

5.5 Develop locally owned business in RE and EE technology ...................................................36

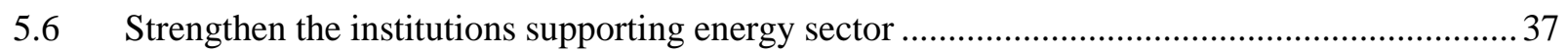

$5.7 \quad$ Fijian government initiative to reduce fossil fuel import.......................................................38

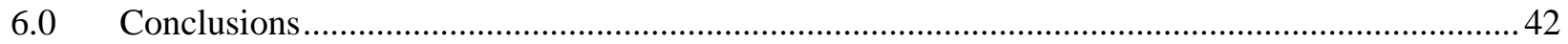

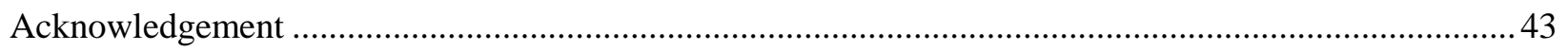

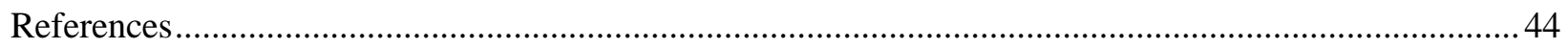

\section{Glossary of Acronyms}

$\begin{array}{ll}\text { Acronym } & \text { Terms } \\ \text { ADO } & \text { Automated Diesel Oil } \\ \text { CBO } & \text { Central Business Organisation } \\ \text { EE } & \text { Energy Efficiency } \\ \text { EEZ } & \text { Exclusive Economic Zone } \\ \text { ESCO } & \text { Energy Service Companies } \\ \text { EYR } & \text { Energy Output Ratio } \\ \text { FBoS } & \text { Fiji Bureau of Statistics } \\ \text { FDoE } & \text { Fiji Department of Energy } \\ \text { FEA } & \text { Fiji Electricity Authority } \\ \text { FiT } & \text { Feed-in-tariff } \\ \text { FJD } & \text { Fijian Dollar } \\ \text { FSC } & \text { Fiji Sugar Cooperation } \\ \text { GCF } & \text { Green Climate Fund } \\ \text { GCPV } & \text { Grid-connected photovoltaic } \\ \text { GDP } & \text { Gross Domestic Product } \\ \text { GoF } & \text { Government of Fiji } \\ \text { GWh } & \text { Gigawatt hours } \\ \text { HFO } & \text { Heavy Fuel Oil } \\ \text { IDO } & \text { Industrial Diesel Oil } \\ \text { IPP } & \text { Independent Power Producers } \\ \text { kW } & \text { kilowatt } \\ \text { LHV } & \text { Lower Heating Value } \\ \text { LPG } & \text { Liquefied Petroleum Gas } \\ \text { MAPE } & \text { Mean Absolute Percentage Error } \\ \text { MOU/A } & \text { Memorandum of understanding/agreement } \\ \text { MW } & \text { Megawatt } \\ \text { PPA } & \text { Power Purchase Agreement } \\ \text { PPP } & \text { Public-Private Partnership } \\ \text { RE } & \text { Renewable Energy } \\ & \end{array}$




\subsection{Introduction}

Knowledge of the past and present energy situation is imperative for a country as it allows decision/policy makers and researchers to strategize and make judicious decisions leading to sustainable development. Sustainable development does not only focus on economic growth but focuses on development that is economically feasible, environmentally friendly as well as socially acceptable [1]. It is even more important in small island developing states (SIDS) which rely heavily on imported fossil fuel for their energy needs, Table 1. According to (UNFCCC, 2005) [2] SIDS' exclusive economic zone (EEZ) is usually larger than their land area and $90 \%$ of the SIDS are in the tropics. Even though renewable resources such as solar, hydro, biomass are being exploited for water heating and electricity generation, most SIDS are still heavily dependent on imported fossil fuel with their volatile prices making SIDS's economies extremely vulnerable. Considering Table 1, most island nations are using biomass for cooking and fossil fuel for electricity generation and transport. Most PICs have targeted to having renewable source of electricity generation.

Fiji is one of the SIDS and lies in the middle of the Pacific Ocean at longitudes between $174^{\circ}$ east and $178^{\circ}$ East and latitudes between $12^{\circ}$ and $22^{\circ}$ South. It has just over 300 islands of which one third are inhabited with a population of 853000 in 2011 [7]. The land area of Fiji is $18,333 \mathrm{~km}^{2}$ where Viti Levu $\left(10,500 \mathrm{~km}^{2}\right)$ and Vanua Levu $\left(5500 \mathrm{~km}^{2}\right)$ are the two largest islands [8]. Fiji's EEZ covers 1.3 million $\mathrm{km}^{2}$ of the South Pacific Ocean. Fiji Electricity Authority (FEA) is the only power utility (established in 1966) and is responsible for generation, transmission and retail of grid electricity on Viti Levu, Vanua Levu and Ovalau ever since. The rest of the islands in Fiji are electrified through diesel generator sets, micro hydro systems or 
generators running on biofuel. The electrification of the off-grid population comes under Fiji Department of Energy (FDoE). .

Table 1

Selected PICs' demography and energy data.

\begin{tabular}{|c|c|c|c|c|c|c|c|}
\hline Parameter & PNG & $\begin{array}{l}\text { Solomon } \\
\text { Islands }\end{array}$ & Vanuatu & Fiji & Samoa & Tuvalu & Tonga \\
\hline $\begin{array}{l}\text { Land area } \\
\left(\mathrm{km}^{2}\right)[3]\end{array}$ & 452860 & 28000 & 12200 & 18333 & 2934 & 26 & 748 \\
\hline $\begin{array}{l}\# \text { of islands } \\
\text { [3] }\end{array}$ & Over 600 & $\begin{array}{l}\text { Nearly } \\
1000\end{array}$ & 80 & 320 & $\begin{array}{l}2 \text { main } \\
\text { islands }\end{array}$ & 8 & 176 \\
\hline $\begin{array}{l}\text { Populations } \\
\text { (million) [3] }\end{array}$ & $\begin{array}{l}\text { Over } 7 \text { (in } \\
2012 \text { ) }\end{array}$ & $\begin{array}{l}0.515870 \\
(2009)\end{array}$ & $\begin{array}{l}0.234023 \\
(2009)\end{array}$ & $\begin{array}{l}837271 \\
(2007) \\
\end{array}$ & 0.187820 & 0.009860 & 0.103036 \\
\hline $\begin{array}{l}\text { Electricity } \\
\text { rate }(\%)[4]\end{array}$ & $13(2010)$ & 14 & 28 & $\begin{array}{l}89 \%(2007 \\
\text { census) }\end{array}$ & 98 & 94 & 89 \\
\hline $\begin{array}{l}\text { Average } \\
\text { electricity } \\
\text { price (FJ } \\
\text { cents/kWh) } \\
{[5]} \\
\end{array}$ & 60.12 & 147.83 & 93.30 & 36.5 & 58.75 & 69.08 & 89.38 \\
\hline $\begin{array}{l}\text { Lighting } \\
\text { source }\end{array}$ & $\begin{array}{l}\text { Kerosene } \\
\text { lamps (over } \\
50 \% \text { ) } \\
\text { open fires (25 } \\
\% \text { ) [3] }\end{array}$ & $\begin{array}{l}\text { Kerosene } \\
\text { Open fire }\end{array}$ & $\begin{array}{l}\text { Kerosene } \\
\text { Open fire }\end{array}$ & $\begin{array}{l}2007 \\
\text { census } \\
\text { data: } \\
\text { Electricity } \\
(78.5 \%) \\
\text { Benzene } \\
(2.4 \%) \\
\text { Kerosene } \\
(18.1 \%) \\
\text { Open fire } \\
(1 \%)\end{array}$ & $\begin{array}{l}\text { Electricity } \\
(97 \%) \\
\text { Kerosene } \\
(3 \%)[3]\end{array}$ & Electricity & $\begin{array}{l}\text { Electricity } \\
\text { Biogas [3] }\end{array}$ \\
\hline $\begin{array}{l}\text { Cooking } \\
\text { source }\end{array}$ & $\begin{array}{l}\text { Fuelwood } \\
(\sim 90 \%) \\
\text { LPG or } \\
\text { Electricity (3 } \\
\%)[3]\end{array}$ & $\begin{array}{l}\text { Biomass } \\
(89 \%)[3]\end{array}$ & Fuelwood & $\begin{array}{l}2007 \\
\text { census } \\
\text { data: } \\
\text { Fuelwood } \\
(42.2 \%) \\
\text { Kerosene } \\
(25.9 \%) \\
\text { LPG } \\
(27.9 \%) \\
\text { Electricity } \\
(3.5 \%) \\
\text { Biogas } \\
(0.4 \%) \\
\end{array}$ & $\begin{array}{l}\text { Fuelwood } \\
(65 \%) \\
\text { Kerosene } \\
(4.5 \%) \\
\text { Electricity } \\
(6.5 \%) \\
\text { Charcoal } \\
(4.3 \%) \\
\text { LPG } \\
(19 \%) \text { [3] }\end{array}$ & $\begin{array}{l}\text { Kerosene } \\
\text { LPG } \\
\text { Biomass } \\
{[3]}\end{array}$ & $\begin{array}{l}\text { Biomass } \\
\text { Kerosene } \\
\text { Electricity } \\
\text { LPG } \\
\text { Biogas [3] }\end{array}$ \\
\hline $\begin{array}{l}\text { Electricity } \\
\text { generation } \\
\text { mix [6] }\end{array}$ & $\begin{array}{l}\text { Hydro } \\
\text { Geothermal } \\
\text { Oil }\end{array}$ & $\begin{array}{l}\text { Mainly } \\
\text { diesel }\end{array}$ & $\begin{array}{l}\text { Diesel } \\
\text { Wind } \\
\text { Solar PV } \\
\text { Biomass } \\
\text { \& biofuel } \\
\end{array}$ & $\begin{array}{l}\text { Hydro } \\
\text { Oil } \\
\text { Wind } \\
\text { Solar } \\
\text { Biomass } \\
\end{array}$ & $\begin{array}{l}\text { Diesel } \\
\text { Hydro } \\
\text { Solar PV }\end{array}$ & $\begin{array}{l}\text { Diesel } \\
\text { Solar PV }\end{array}$ & Diesel \\
\hline RE \% in & 58 & 0.2 & 8.5 & 59.4 & 32 & 0.6 & 0.0 \\
\hline
\end{tabular}


The access to electricity in Fijian households in not $100 \%$. From the last 3 consecutive censuses data, in 1986, 1996 and 2007, $48 \%, 67 \%$ and $89 \%$ of households have access to electricity [9]. Electricity is provided by FEA (grid-connected) or distributed generators such as solar home systems or diesel generators or biofuel generators or micro hydro schemes. In 2007, $75 \%$ of the Fiji's population had grid electricity while $14 \%$ of the rural population had access to distributed electricity [59. $100 \%$ of both rural population and urban population has access to modern forms of lighting while $29 \%$ of rural and $85 \%$ urban population had modern cooking fuel (all types of fuels except traditional biomass) [10-11]. The consumption of final energy by different sectors (residential, industry and transport) is shown in Fig. 1. Industrial sector is the largest for final energy consumption.

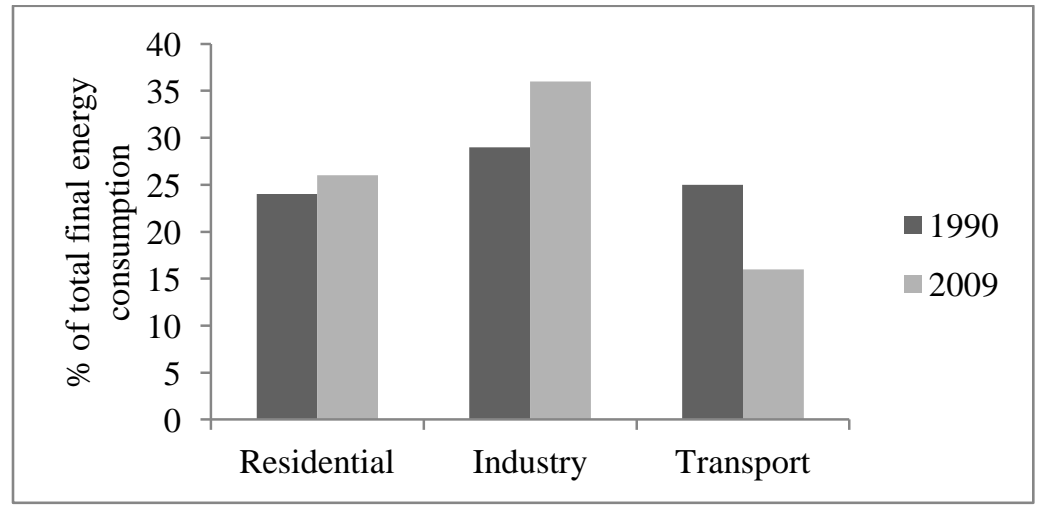

Fig. 1. Energy consumption by sector, 1990-2009 [12].

FEA began hydro power production on large scale in 1982 (80 MW Monasavu Hydro Power) and escalating fuel prices from 2004 has motivated FEA to turn to renewable energy sources for electricity generation. FDoE started with setting up diesel generators in outer islands for lighting sources but recently from 2010 islanders are more interested in solar home systems. Transport sector is dominated by used of fossil fuels and there has been very minute change in in terms of replacement of fossil fuels with other clean and local fuel. However, government, academic institutions and other stakeholders are rigorously working towards finding some workable solutions. Fiji's commitment for clean source of energy is evidenced by its various actions plans and its communications to UNFCCC. 
The objective of this paper is to study the past and present energy situation in Fiji in terms of the energy resources available, electricity generation and consumption and consumption of imported fossil fuel. In addition, challenges and threats prominent to Fiji as a SIDS are to be identified and strategies to overcome these are to be discussed. This will help Fiji form concrete strategies towards achieving its Nationally Determined Contributions (NDC). Fiji's NDC [13] was developed to achieve the objective of the UNFCCC which is consistent with Green Growth Framework 2014 (GGF) [14] and Sustainable Energy for All (SE4ALL) initiative of United Nations [15]. The NDC start in 2020 and end year is 2030. Its targets are reducing the import of diesel and heavy fuel oil to 200 million litres, close $100 \%$ renewable electricity and emission reduction of $30 \%$ by 2030 .

Based on the data and information collected and analysed from Fiji Bureau of Statistics (FBoS), FEA, FDoE, and also from various stakeholders via personal visits, telephone and email correspondence, the objectives of this paper is achieved. The next section presents population and economic growth in Fiji, followed by past and current energy situation. This leads to the discussions on challenges and threats to energy access in section 4 . Section 5 discusses strategies that would help Fiji overcome some of the challenges and threats to its energy security and access. These discussions will be beneficial for potential investors in renewable and energy efficiency in Fiji and also to government and non-government organizations.

\subsection{Fiji's population and economic growth}

The energy demand is greater in urban areas than in the rural areas mainly due to the high population and relatively high income compared with rural areas. High income earners tend to increase their end use energy demand such as for electricity, fuel usage for transport and activities which are highly energy intensive. For Fiji, the population in the urban and rural areas is shown in Table 2. From 1986 to 1996, urban population increased by $30 \%$ while the rural population decreased by $5 \%$. In the next decade (1996 to 2007) urban population increased by $18 \%$ while rural population decreased by $0.8 \%$. The percentage of urban population increases mainly due to more job opportunities in urban areas than in rural areas or remote islands. For rural areas, jobs are mainly available in agriculture /farming and fishing sectors. In 2008 average rural household size was 4.8 persons compared to 5 in 2002 while the average household size for urban areas was 4.5 persons in 2008 compared to 4.7 in 2002 [16]. It is projected, that by 2030, Fiji's population will reach the 1 million. 
Table 2

Population distribution in urban and rural areas in Fiji.

\begin{tabular}{|l|l|l|l|l|l|l|l|l|l|l|l|l|l|}
\hline & \multicolumn{90}{|c|}{ Population } \\
\hline & \multicolumn{1}{|c|}{$\begin{array}{c}1986 \\
\text { (census data) }\end{array}$} & \multicolumn{2}{c|}{$\begin{array}{c}1996 \\
\text { (census data) }\end{array}$} & \multicolumn{2}{c|}{$\begin{array}{c}2007 \\
\text { (census data) }\end{array}$} & $\begin{array}{c}2010 \\
\text { (Projected) }\end{array}$ & \multicolumn{2}{c|}{$\begin{array}{c}2020 \\
\text { (Projected) }\end{array}$} & \multicolumn{2}{c|}{$\begin{array}{c}2030 \\
\text { (Projected) }\end{array}$} \\
\hline & Amount & $\%$ & Amount & $\%$ & Amount & $\%$ & Amount & $\%$ & Amount & $\%$ & Amount & $\%$ \\
\hline Urban & 277025 & 39 & 359495 & 46 & 424846 & 51 & 446000 & 52 & 527000 & 56 & 629000 & 61 \\
\hline Rural & 438350 & 61 & 415582 & 54 & 412425 & 49 & 411000 & 48 & 409000 & 44 & 405000 & 39 \\
\hline Total & $\mathbf{7 1 5 3 7 5}$ & & $\mathbf{7 7 5 0 7 7}$ & & $\mathbf{8 3 7 2 7 1}$ & & $\mathbf{8 5 7 0 0 0}$ & & $\mathbf{9 3 6 0 0 0}$ & & $\mathbf{1 0 3 4 0 0 0}$ & \\
\hline
\end{tabular}

Source: Fiji Bureau of Statistics [8].

The historical data for gross domestic product (GDP) at current factor cost and GDP per capita and annual population data were obtained from FBoS [7]. These data are presented in Fig. 2. The average annual population growth rate from 1968 to 2011 is determined to be $1.3 \%$ with a maximum annual growth rate of $3 \%$ and minimum of $-0.3 \%$. The decrease in population growth occurred in 1988 due to the first political upheaval (overthrowing of democratically elected government by military) in 1987 which lead to migration of a fair percentage of population [17]. If the annual growth rate in population is taken as $1 \%$ on average, then by 2030 the population of Fiji would just cross the 1 million mark. 
GDP is a measure of a country's economic performance and gauges a country's standard of living [18]. GDP is the sum of private and public consumption, government outlays, investments and exports less imports that occurs in a nation over a specific time. Fiji's economy has grown substantially over last 4 decades. Considering Fig. 2, the average annual growth rate for GDP from 1968 to 1980 was $17.4 \%$, from 1981-2000 it was $6.5 \%$ and then from 2001-2010 it was $5.3 \%$. However, there are a number of negative growths in GDP due to internal and external factors. The major internal factor is the political upheaval in 1987, 2000 and then again in 2006 which saw a decline in country's economic performance [19]. In addition, external factors such as spike in food and fuel prices in 2008 and global economic crisis in 2009 [19] also reflect in the negative growth.

Manufacturing industry contributed the most to the GDP in 2013, followed by transport, storage and communication and then by real estate and business, (Fig. 3). However, it should be noted that tourism industry (hotels, restaurants and transport) which has grown over the past years, is 
one of the main drivers of the economy and is the largest source of foreign exchange [20]. Tourism earnings contribution to GDP from 2011 to 2013 is $24 \%$ to 22\% [21]. Each sector, in Fig. 3, one way or another relies on energy either in the form of electricity, fuel for heat or cooking or fuel for transport for its progress.

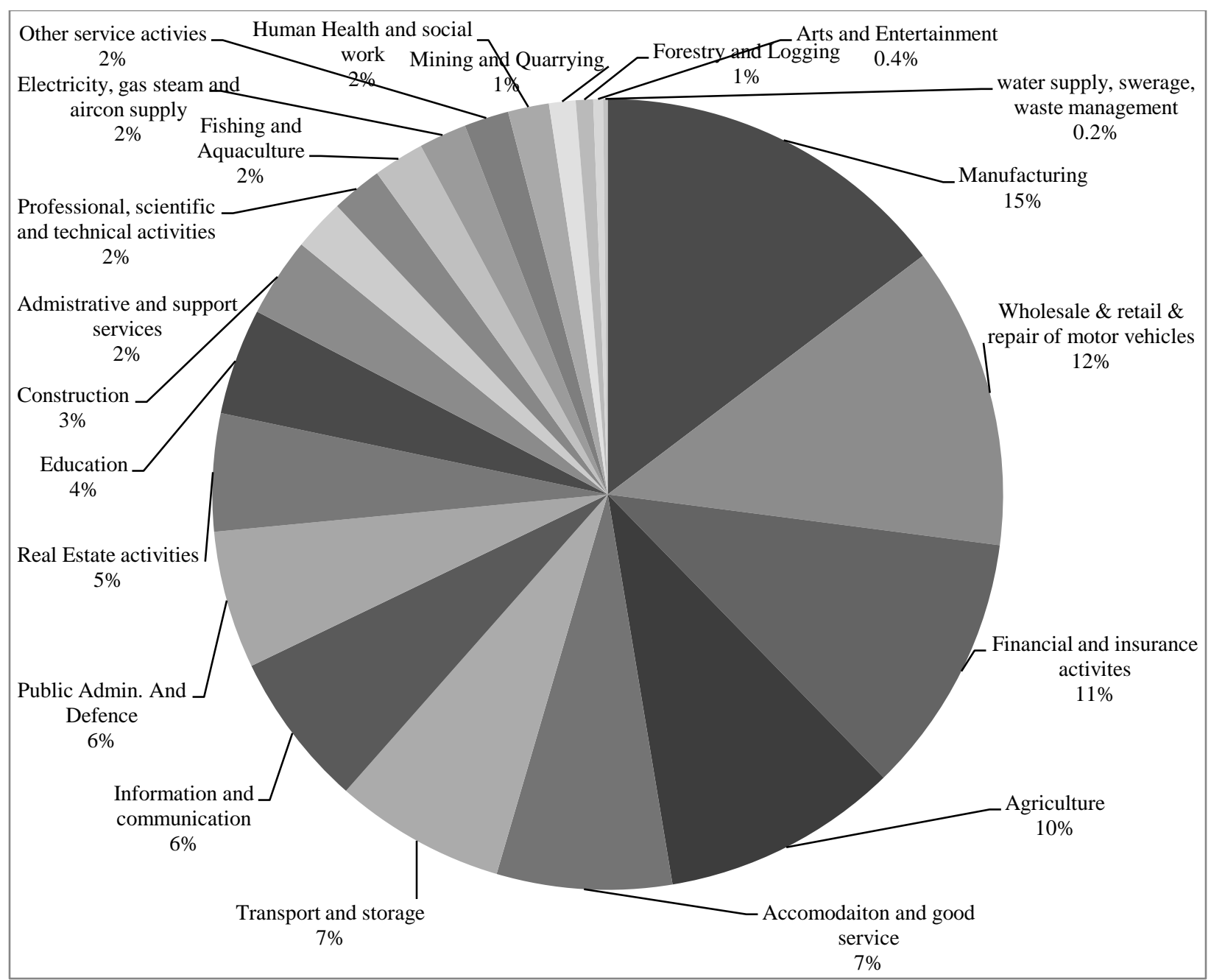

Fig. 3. Share of different sectors towards GDP at current basic prices for year 2013.

Data Source: Fiji Bureau of Statistics [8].

\subsection{Current energy situation in Fiji}

Fiji's economy has been growing steadily over the past decades resulting in increasing demand for energy in industrial, transportation, agriculture, tourism and commercial sectors. The energy 
situation in Fiji is described below in terms of available energy resources, electricity generation and energy consumption.

\subsection{Energy Resources}

Fiji neither has any fossil fuel energy resources nor any nuclear power stations. It imports all its fuel requirements for transportation and electricity. Renewable energy resources are mainly used for electric power generation. Due to geographical location of Fiji, it has good renewable energy resources such as solar, wind, biomass and hydro. The following sub-sections describe the situation vis-à-vis these resources.

\subsubsection{Solar Energy}

Annual solar insolation on horizontal surface in Fiji ranges from $4800 \mathrm{MJ} / \mathrm{m}^{2}$ to $8900 \mathrm{MJ} / \mathrm{m}^{2}$. The western side of Fiji is the dryer side of the country with higher solar insolation compared to the central or eastern side. Solar home systems (SHS) are commonly used in remote area and outer islands in Fiji and by the end of 2014 installed capacity for SHS will be $1170 \mathrm{~kW}$, comprising approximately 5,800 units [22]. Grid-connected photovoltaic (GCPV) system is gaining momentum in Fiji and there are about 1.7 MW of GCPV and mini off-grid solar PV systems installed.

\subsubsection{Wind Energy}

FDoE has set up wind monitoring stations at various locations in Fiji where there was a potential of good wind regime. The wind map created by AWS Truewind reveals that at $45 \mathrm{~m}$ height, Northern and Western part of Viti Levu, wind speeds are more than $6 \mathrm{~ms}^{-1}$ while the interior or highlands in Viti Levu and Vanua Levu wind speeds are more than $4.5 \mathrm{~ms}^{-1}$ [23]. This corresponds to class 2 and class 3 of wind power density ranging from 200 to $400 \mathrm{Wm}^{-2}$. Presently, Fiji has a $10 \mathrm{MW}$ wind farm which was installed and commissioned by FEA in 2007 and so far it has generated $33.4 \mathrm{GWh}$ i.e. 120 TJ. This operation has saved FEA FJD12 million in diesel fuel cost and about 22 ktonnes of $\mathrm{CO}_{2}$ emission by 2012 [24].

\subsubsection{Hydro power}

Hydro power makes the largest contribution from renewable energy resources for electricity production in Fiji. Currently, there is $130 \mathrm{MW}$ of installed capacity of hydro power out of which $0.18 \mathrm{MW}$ is installed by FDoE for off-grid power while the rest is installed by FEA (gridconnected). FDoE has started works on a $700 \mathrm{~kW}$ mini hydro in Taveuni with the help of Chinese government. In addition, FDoE has done hydro preliminary study for various sites around Fiji and found out 22 sites mainly in Vanua Levu and other smaller islands feasible for 
further long-term monitoring (2-3 years) [25]. Small hydro power (less than $1500 \mathrm{~kW}$ ) potential in Fiji is around 14.7 MW [26]. Belena of FDoE [27] reports that Vanua Levu has 3 MW while Viti Levu has 83.3 MW of hydro potential.

\subsubsection{Biomass energy}

Fiji has huge biomass resource; $58 \%$ of its land area is covered by forests and agriculture is the $6^{\text {th }}$ largest contributor to the GDP. $89 \%$ of the forest cover comprises indigenous trees while remaining $11 \%$ are exotic plantations (pine and mahogany) [28]. From 2001 to 2011, annual log production was $413,887 \mathrm{~m}^{3}$ where $74.7 \% \log$ production was from pine plantations, $19.7 \%$ from indigenous forest and $11.6 \%$ from mahogany plantations [29]. During timber production in sawmills, approximately $40-70 \%$ of waste are generated in the form of slabs and sawdust [30] which can be used for energy production.

Byproduct of sugar production, bagasse is used in cogeneration of heat and power in the four sugar mills of Fiji Sugar Cooperation (FSC). From 2007 to 2010, 2.2 Mtonnes of sugar cane was crushed annually in Fiji [31]. Pine sawdust is used by Tropik Wood Industries Ltd. (TWIL) to generate electricity mainly for their use. FSC has a total of $16 \mathrm{MW}$ plant capacity while TWIL has an installed capacity of 12.3 MW [32-33]. In 2010-11, the total surplus electricity exported to FEA grid by FSC and TWIL together was 25,150 MWh. Prasad [34] reports that FSC has a potential of $60 \mathrm{MW}$ plant capacity capable of producing year around electricity.

\subsubsection{Geothermal}

Presently, Fiji does not have geothermal power plants, however, feasibility studies have been carried out at some locations and significant potential has been found. Fiji has 53 thermal areas around the country where surface temperature ranges from 31 to $102^{\circ} \mathrm{C}$ which makes some of them contender for geothermal applications [35-36]. Vanua Levu has a potential of more than 23 MW while Viti Levu has 15.2 MW [37]. Overall, a geothermal power potential between 50 to 70 MW has been calculated [38-39].

\subsection{Grid electricity generation by source and peak demand}

By the year 2014, the total installed generation capacity for FEA was approximately $259.8 \mathrm{MW}$ comprising 135.6 MW hydro, 114.2 MW diesel and 10 MW wind. A total of 14 diesel electricity generation stations are on Viti Levu, Vanua Levu and Ovalau, where $92 \mathrm{MW}$ is installed on Viti Levu [40]. Biomass installed capacity is 28.3 MW by Independent Power Producers (IPP) namely FSC and TWIL [32-33]. Transmission is provided via $145 \mathrm{~km}$ of 132 
$\mathrm{kV}$ lines and $350 \mathrm{~km}$ of $33 \mathrm{kV}$ lines. Power distribution is achieved with more than $8000 \mathrm{~km}$ of $11 \mathrm{kV}$ and 415/240 V lines [40]. The peak demand for the three main islands is shown in Table 3. From 2011 to 2012 there is a $7 \%$ increase in peak demands on Viti Levu and Ovalau and $3 \%$ increase on Vanua Levu.

\section{Table 3}

Peak demand for grid electricity on main islands [41].

\begin{tabular}{|l|l|l|l|l|}
\hline & \multicolumn{4}{|c|}{ Peak Demand (MW) } \\
\hline Year & Viti Levu & Vanua Levu & Ovalau & TOTAL \\
\hline 2011 & 152.3 & 12.4 & 2.8 & 167.5 \\
\hline 2012 & 162.5 & 16.1 & 3 & 181.6 \\
\hline
\end{tabular}

The base-load on Viti Levu is provided by hydroelectricity and during peak hours diesel generators compensate for the excess demand. On the other two main islands (Vanua Levu and Ovalau), grid electricity is provided by diesel generators. Grid electrical energy generated by different sources is shown in Fig. 4. There are three distinct periods for hydroelectricity generation. From 1998 to 2002, there is an average annual generation of $439 \mathrm{GWh}$; which followed a decrease in generation (annual average $348 \mathrm{GWh}$ ) from 2003 to 2006, and an increase again of an annual average generation of $477 \mathrm{GWh}$ from 2007. Low water level at the Monasavu dam was the main factor which contributed to the dip in hydro electricity generation. Diesel generators (running on industrial diesel oil (IDO) and heavy fuel oil (HFO)) have been contributing a higher percentage of electrical energy since 2003. In 2012, $64 \%$ of the electricity was generated from hydro, $33 \%$ from diesel fuel while remaining $3 \%$ was from biomass and wind. 


\subsection{Energy Consumption}

\subsubsection{Electricity consumption}

\subsubsection{Electricity consumption and generation}

Considering 1979 - 2012 data, the annual average electricity production and consumption is found to be 590 million $\mathrm{kWh}$ and 470 million $\mathrm{kWh}$ respectively (Fig. 5). This corresponds to an average percentage difference with respect to production of $20 \%$. Production includes electricity generated by FEA and any other independent power producer (IPP). On average there is $4.2 \%$ increase in annual electricity production and consumption. The income from sales of electricity has been rising over the years due to increase in tariff rate charged by FEA. 
Fig. 5. Electricity generated and consumed in Fiji.

Data Source: Fiji Bureau of Statistics [7]

Considering, Fig. 5, there is a linear increase in production and consumption of electricity. Creating a linear trend line from this data gives the equations shown in Table 4 along with their $\mathrm{R}^{2}$ value. The mean absolute percentage error (MAPE) for production projection is $7.6 \%$ while for consumption projection it is $7.4 \%$. Based on this, the production value in 2025 would be 1,136 million $\mathrm{kWh}$ while consumption would be 1,025 million $\mathrm{kWh}$. 


\section{Table 4}

Linear projection equation for production and consumption of electricity in million $\mathrm{kWh}$.

\begin{tabular}{|l|l|l|}
\hline & Production & Consumption \\
\hline $\begin{array}{l}\text { Linear projection Equation } \\
(\text { Million } \mathrm{kWh})\end{array}$ & $\mathrm{y}=18.356 \mathrm{x}-36035$ & $\mathrm{y}=18.91 \mathrm{x}-37268$ \\
\hline $\mathrm{R}^{2}$ value & 0.9734 & 0.9554 \\
\hline $\begin{array}{l}\text { Mean Absolute Error (MAE) } \\
\text { (million kWh) }\end{array}$ & 32.3 & 32.8 \\
\hline $\begin{array}{l}\text { Mean Absolute Percentage } \\
\text { Error (MAPE) }\end{array}$ & 7.6 & 7.4 \\
\hline
\end{tabular}

\subsubsection{Domestic and Non-domestic electricity consumption}

From 2007 census data, $75 \%$ of households have grid connected electricity while $89 \%$ of households had electricity either from grid or distributed generation. Only $4 \%$ and $19 \%$ of the households in urban and rural areas respectively were without electricity [9]. In central, western and northern provinces there were 15, 21 and $36 \%$ rural households without grid electricity which implies that rural electrification is a challenge since population is scattered and extending grid power to these areas is significantly expensive [42].

By 2012, FEA had $89 \%$ domestic customers and $11 \%$ non-domestic customers. Out of the 11 $\%, 9 \%$ are industrial and commercial customers while the remaining $2 \%$ is institutions such as primary, secondary schools and place of worship [43]. The domestic customers consume only $28 \%$ of the total electricity consumed while the remaining $72 \%$ is consumed by the nondomestic sector (Fig. 6). Even though the number of non-domestic customers is significantly low, their consumption is high. The average annual growth rate of electricity consumption of non-domestic customers is $5 \%$ while that of domestic customers is $7 \%$. Average annual electricity consumption per capita is determined to be $850 \mathrm{kWh} /$ capita. 


\subsubsection{Fossil fuel consumption}

Fossil fuel is used in all sectors of the nation, especially in the transport sector. Fiji imports all of its fossil fuel which putting a heavy burden on foreign reserves. Narayan et al. [45] report that over the period from 1996 to 2005 when the crude oil prices increased from USD 23/barrel to over USD 55/barrel foreign reserves in Fiji declined from equivalent to 6 months imports to 2.5 months import. According to Macrotrends [46], in 2000, the global crude oil price was approximately USD37/barrel which steadily increased to a peak in July 2008 with a price of USD140/barrel. From 2011 to present, the global price is fluctuating between USD90110/barrel.

Fiji does not have any "in country" conventional fuel source. It imports all mineral fuel products. Australia, New Zealand and Singapore are the top three countries from where fuel is imported in Fiji. Part of this imported fuel is then re-exported to other Pacific Island Countries. 
Considering FBoS data from 2000-2013, retained import of mineral products make up an average of $21 \%$ of the total annual import bill (Fig. 7). Fuel import bill has been increasing for Fiji (Fig. 7) reaching a peak in 2008 with retained fuel import bill of FJD 1.2 billion due to peak in global crude oil price.

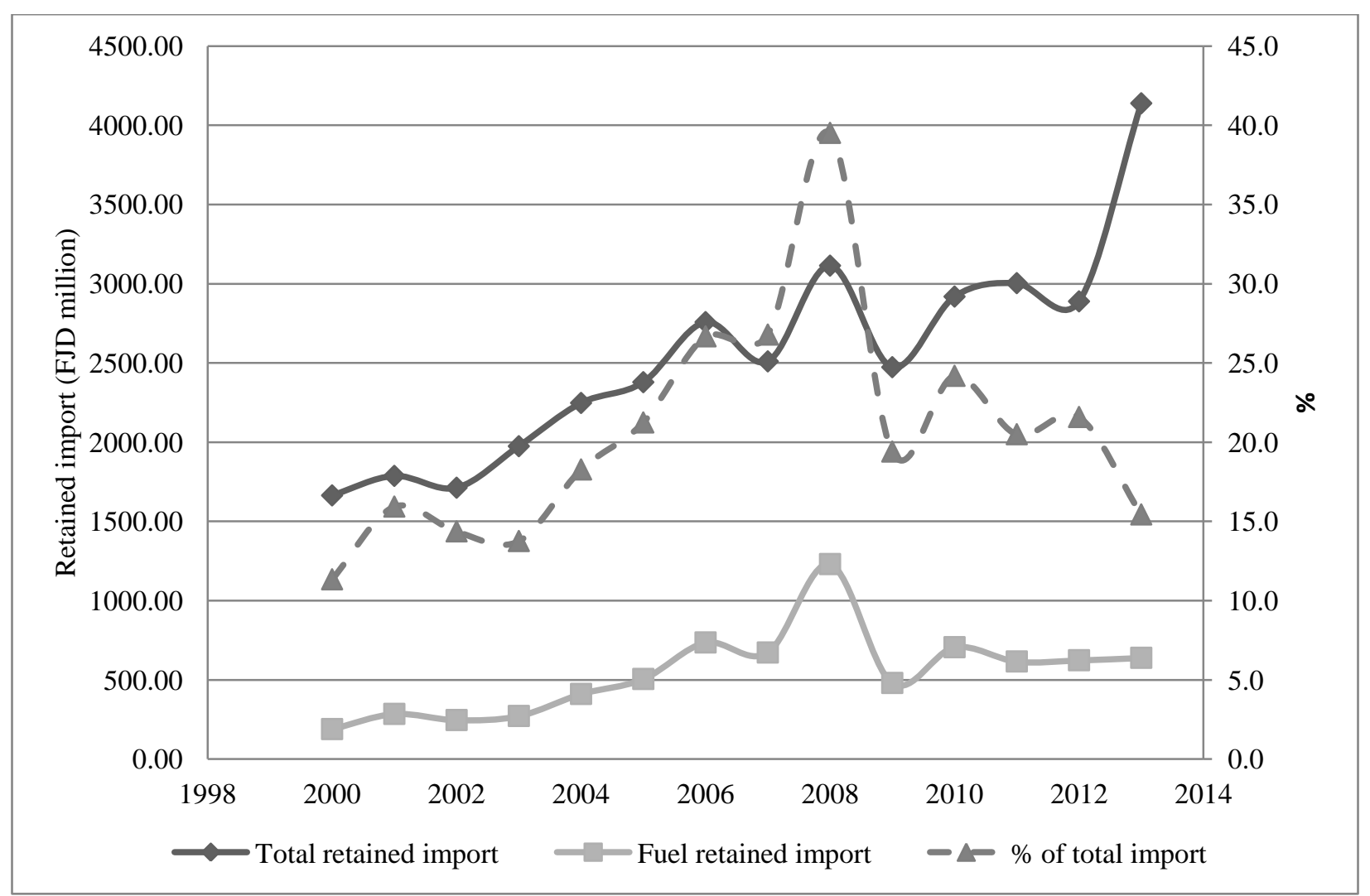

Fig. 7. Retained mineral import in Fiji.

Data source: Fiji Bureau of Statistics [47-48].

\subsubsection{FEA fossil fuel usage}

The cost and amount of thermal fuel (IDO and HFO) used for FEA grid-connected electricity is shown in Fig. 8. Even though, the $\%$ share of electricity generation from thermal fuel has decreased from 2009 (Fig. 4) but from Fig. 8, the cost of fuel has increased in this period. This is attributed to the increase in global price for thermal fuels. For the past 4 years the fuel import bill for FEA varies between FJD100-140 million. The consumption of thermal fuel usage for electricity generation is fluctuating, which supplies electricity once the hydroelectric power plants are not able to meet the demand. 


\subsubsection{Transport and industrial sector fossil fuel usage}

The different fuels used in transport and industry sectors in Fiji are shown in Figures 9 and 10. Overall, diesel consumption is high (annual average of 360 million liters $(71 \%)$ ) in the country compared to jet fuel (125 million liters (23\%)) and HFO (30 million liters $(6 \%))$ as it is used in 
transport industry as well in the power generation (Fig. 9). Diesel and petroleum fuel for transport has annual average consumption of 202 million liters. This is on average $56 \%$ of the total diesel and petroleum oil consumption. Annual average total transport fuel (jet fuel, diesel and petroleum fuel) is 326 million liters.

From 2007, there has been sharp increase in import of liquefied petroleum gases (LPG) (Fig. 10). Before 2006, annual average consumption of LPG was 12.6 million $\mathrm{kg}$ which increased to an annual average of 18.6 million kg from 2007 to 2013. On average, LPG import in Fiji increases by $5 \%$ annually. The increase from 2007 is mainly due to the government removing import duty on LPG vehicles.

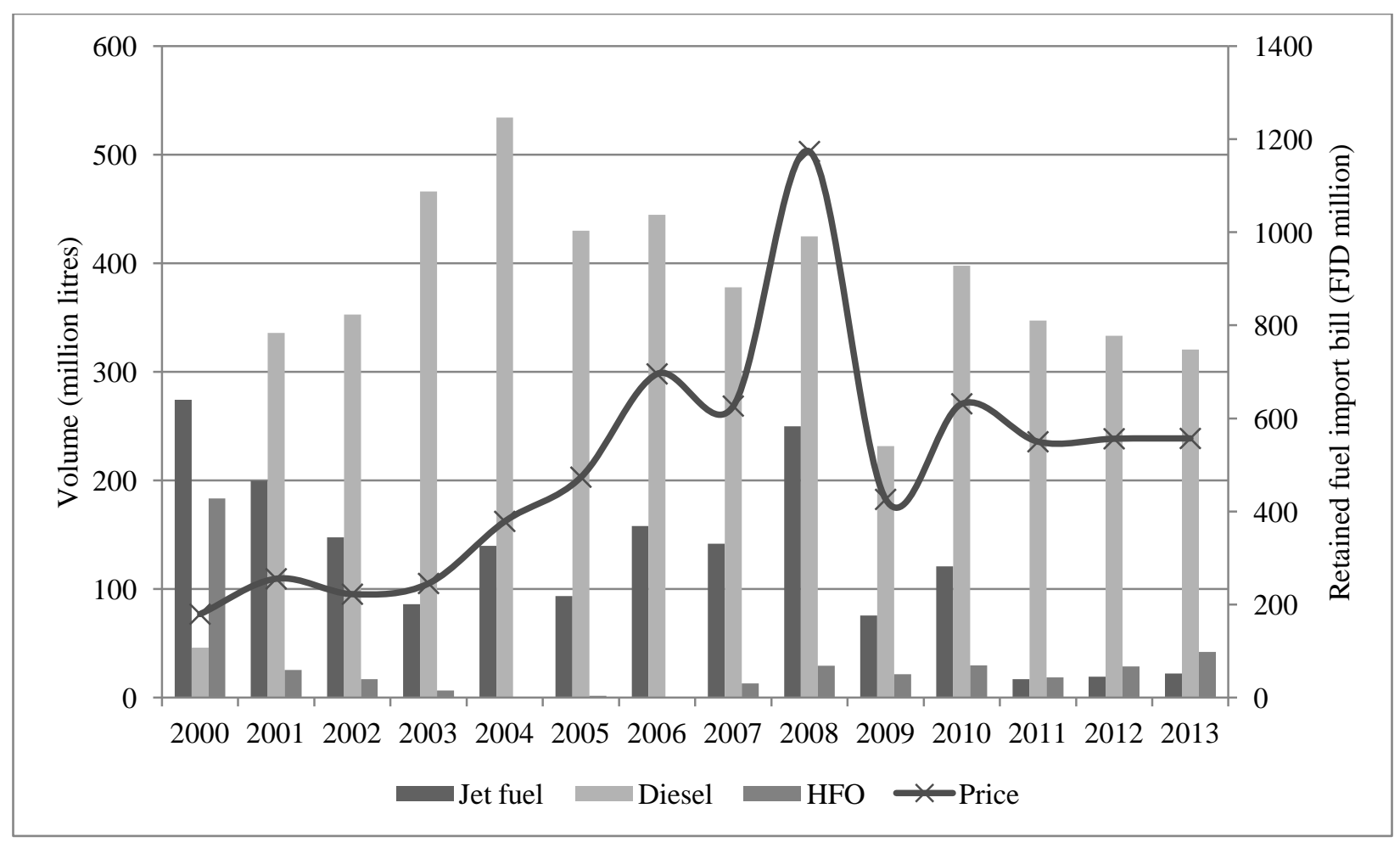

Fig. 9. Transport and industry fuel use. Data Source: [47]. 


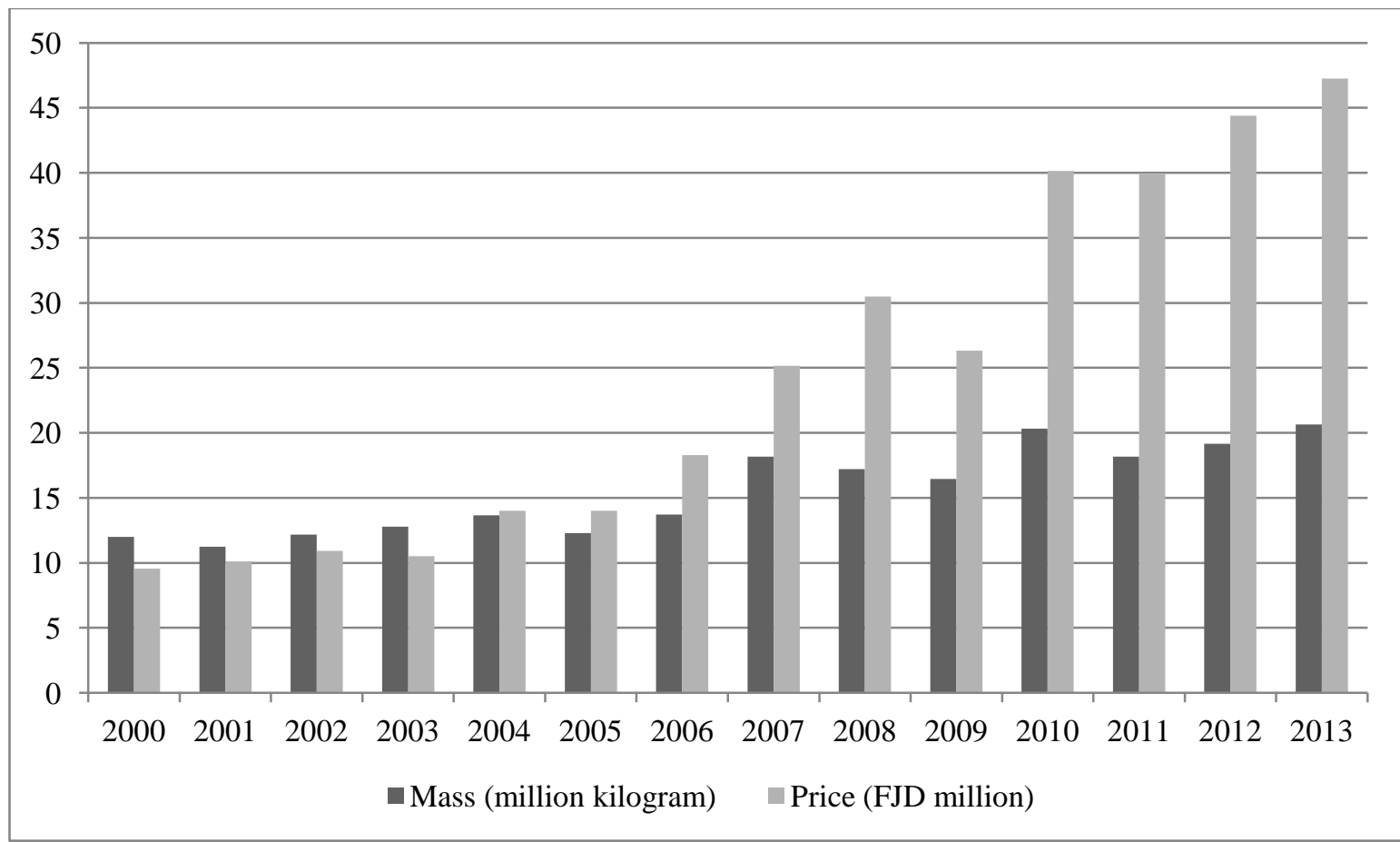

Fig. 10. LPG import in Fiji. Data Source: [47].

\subsection{Energy conservation and efficiency}

FDoE is the lead institution in Fiji that creates public and private sector awareness on energy conservation and efficiency through talk shows, media advertisements, competitions and helps carrying out preliminary energy audits for buildings. It also regulates and implements standards and labeling for refrigerators and freezers. Importers of freezers and refrigerators have to seek approval from FDoE on importing these products to ensure that only products which are compliant with Fiji/Australia/New Zealand Standards FS/AS/NZS 4474.1 and FS/AS/NZS 4474.2 are imported and affixed with energy star rating [50]. FEA also educates its customers on energy saving habits to help reduce their electricity bills.

Work in underway for FDoE to improve Fiji's building code so that the buildings use energy conservatively and efficiently. The first phase of this project has been completed with a status report and recommendations on what needs to be done to amend the Fiji National Building Code published [51].

\subsection{Challenges and threats}


Fiji has energy challenges and threats which are unique to SIDS. The following sub-sections discuss some of these which exist in Fiji.

\subsection{High susceptibility to natural disasters}

Fiji experiences floods, landslides and cyclones every year. This is due to the location of Fiji in the South Pacific Convergence Zones and mountainous volcanic islands. Tropical cyclones season is from November to April each year with an average of 2 cyclones per year. Over the past decade there has been average of 17 cyclones in total [52].

River flooding occurs every wet season and most landslides occur during heavy rainfall. Severe droughts do not occur every year but in recent times have occurred in 1987, 1992, 1997/98, 2003 and 2010 [53].

These natural disasters may have adverse effect on renewable energy projects if not planned properly.

\subsection{High ratio of fossil fuel import to total export in Fiji}

Since 2005, more than $50 \%$ of the export earnings have gone towards importation of mineral fuel products (Fig. 11). Years 2006 to 2008 have been the worst years where more than $80 \%$ of the export earnings have contributed to fossil fuel import. However, when tourism earnings are also considered then fuel import bill as a \% of total earnings (export plus tourism) reduces to an annual average of $40 \%$.

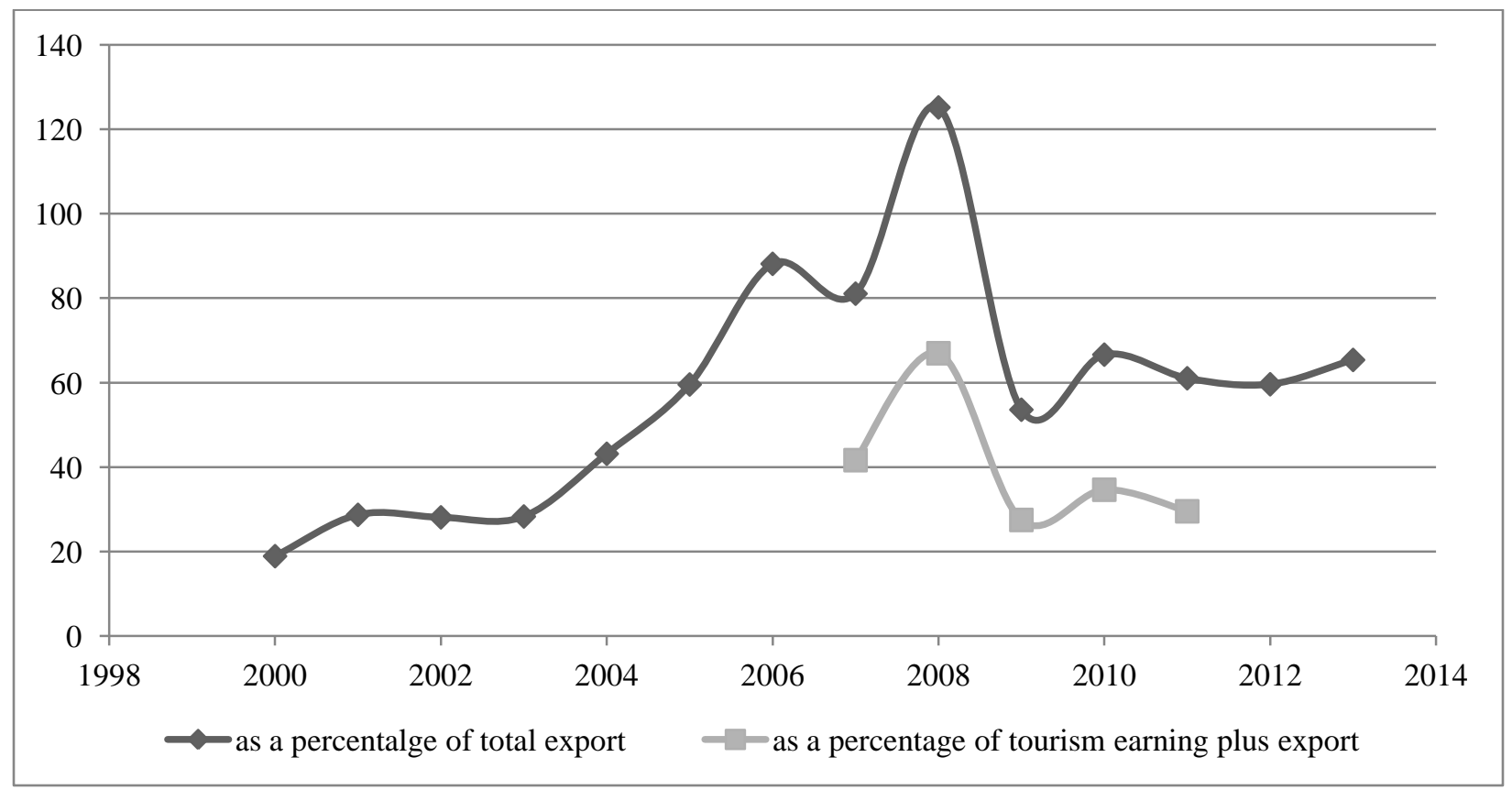


Fig. 11. Retained mineral fuel import as a \% of export in Fiji. Data Source: FBoS [47-48].

\subsection{Dispersed islands within an island country}

Dispersion of islands in Fiji makes it difficult to provide grid electricity on every island. Hence, only three major islands have grid electricity while the rest have electricity access through REU of FDoE and resorts on islands have their own diesel generators. For modern electricity access to remote areas and outer islands in Fiji, SHS are implemented which have partial Renewable Energy Service Company (RESCO) approach where SHS remain the property of FDoE, while private companies are contracted to provide service for a fee [54]. Studies carried out on RESCO in Fiji, reveal that problems exists in this approach such as replacement of parts takes a long time, private companies are not making enough profit (due to small number of SHS and low tariff FJD14/month which does not cover the maintenance costs) to invest technical expertise and management capacity [54-55].

Fuel wood is the energy source for cooking in majority of the remote islands as well as in interior of the main islands. According to the 2007 census data, $61 \%$ of rural households use wood open fire for cooking while only $2 \%$ use electricity. In urban areas, LPG is the dominating source of cooking fuel ( $45 \%$ of urban households), followed by kerosene (35\% of urban households). This leads to the challenge of providing modern fuel for cooking in rural areas. Transportation cost of modern fuels (kerosene and LPG) from mainland to smaller outer islands is significant. In addition, there is also the issue of availability of boat or ships to transport fuel to remote islands.

\subsection{Slow growth of RE sector in Fiji}

Even though fossil fuel is expensive it is still widely used in Fiji. Renewable energy sources are used as alternative energy but its growth rate is very slow. Fiji does not have any RE manufacturing companies. RE and EE technologies in Fiji are brought from developed countries called horizontal technology transfer where a fully commercialized technology is transferred from one geographic location to another [56]. The following sub-sections discuss the growth rate of different $\mathrm{RE}$ technologies.

\subsubsection{Solar}

Solar home system (SHS)

The pilot project of SHS started in 2002 by FDoE and there has been significant increase in the number of SHS installed from 2012 (Fig. 12). 


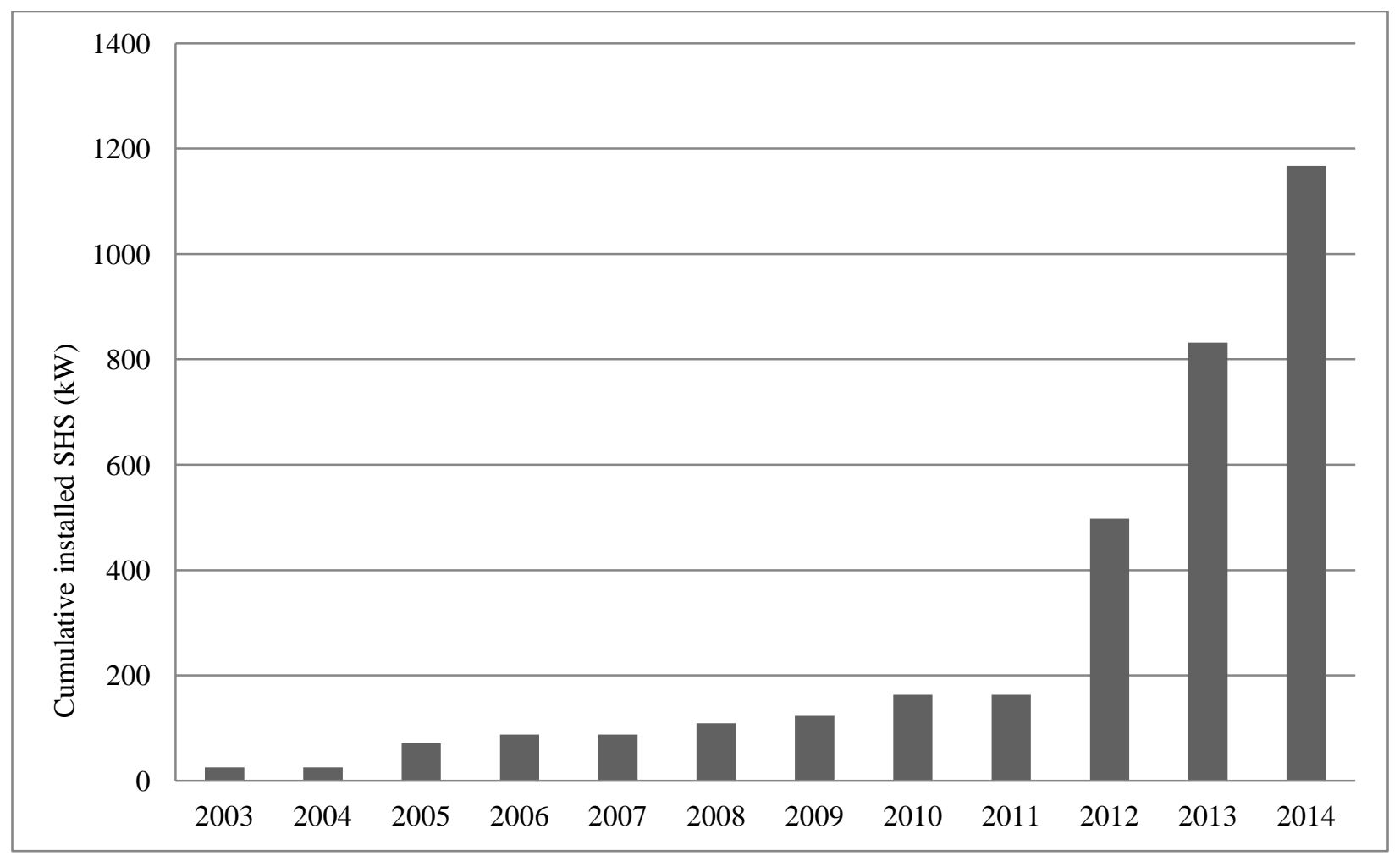

Fig.12. Growth in installed capacity of SHS in Fiji. Data Source: [22].

During 2003-2010, SHS units were $100 \mathrm{~W}$ each and were mostly installed in Vanua Levu using Government of Fiji (GoF) funds. However, from 2012, Japanese funds were available which ensured SHS installation in maritime areas. Since then, 1000 SHS units have been installed where each unit was $270 \mathrm{~W}$ leading to $17 \%$ of total SHS installation in outer islands [22].

Before 2010, people were mostly opting for FEA grid extension to their homes or diesel generator system for rural electrification [22]. It can be seen from Fig. 13, that until 2009 diesel generator installation have been significant in outer islands and remote areas where FEA grid cannot be extended. During this time the cost of diesel was manageable by households and also SHS was not very popular. However, once the price of diesel increased and awareness on SHS were made to people by FDoE, people in outer islands were interested, showed by sharp increase in SHS from 2012 (Fig. 12) and sharp decrease in diesel generator set installation in 2011 and 2012 (Fig. 13). People came to realize that even though initial cost of diesel generators is relatively cheap compared to solar, its running cost over its lifetime is much costly due to its fuel cost which is further increased due to transportation costs to remote and outer island locations. 


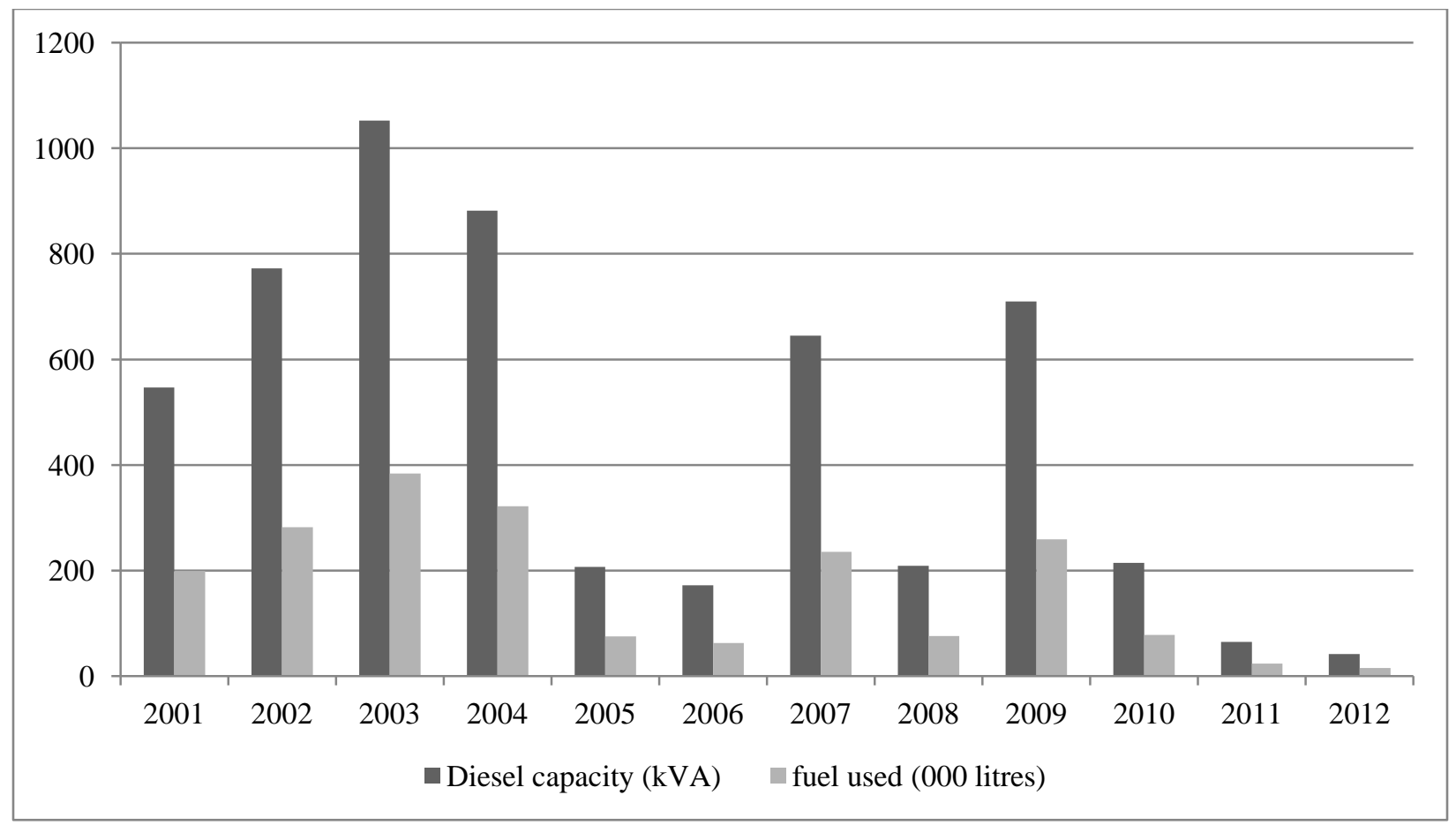

Fig. 13. Annual diesel generator installation and volume of fuel used. Data source: [57].

\section{Solar PV mini off-grid and grid connected}

Two companies in Fiji are actively involved in installation of GCPV or mini off-grid PV system in Fiji. GCPV systems have been installed however; currently it is not feeding into the grid. These remain off-grid. Mini off-grids are mostly used on island resorts. Two resorts have installed solar PV mini grid for their energy usage. The total mini off-grid and GCPV connected from 2012 to 2014 is $1743.35 \mathrm{~kW}$ [58-64].

\section{Solar water pumps and solar lights for jetties}

FDoE has carried out these installations. From 2007 to 2009, 4 villages have solar water pumps while 3 jetties have been installed with solar lights [22].

\subsubsection{Hydro}

FEA has installed approximately $130 \mathrm{MW}$ of hydro power schemes mostly in Viti Levu with just 1.6 MW in Vanua Levu. While FDoE has installed $180.3 \mathrm{~kW}$ out of which only $30.3 \mathrm{~kW}$ is currently working in 2014 [65]. On the remaining $150 \mathrm{~kW}$ rehabilitation work is being carried 
out. In 1982, Fiji's first megawatt grid-connected hydro power scheme (80 MW) was installed. There was no significant increase in hydro capacity till 2002. From 2003 to 200610.8 MW was added by FEA while in 201240 MW Nadarivatu Hydro Scheme came online [66].

\subsubsection{Biomass}

\section{Traditional biomass}

This is referred to the widespread use of firewood for cooking purposes. In 2008, $19 \%$ of urban households used fuelwood for cooking while $77 \%$ of rural households were using wood [42]. Since the number of electric and gas stoves remain relatively unchanged from 2002 to 2008 , increase in wood fuel consumption is due to increased availability of mahogany cut-offs in the market [42].

\section{Biogas}

Biogas digesters are installed in rural areas to replace LPG fuel for cooking. The FDoE has been installing this technology over the past decade funded by GoF. From 2009 to 2012, there are total of 14 biogas digesters installed in Fiji [67]. Out of this to date 10 are operational of size $111 \mathrm{~m}^{3}$. The main reason for biogas digesters not operating are less feedstock or digesters were not maintained properly [67]. All the biogas digesters are in the central division.

\section{Biofuel for electricity generation}

Information gathered from FDOE reveals that till 2012, a total of $5518 \mathrm{kVA}$ diesel generator capacity had been installed in rural areas. Out of this diesel capacity $1551 \mathrm{kVA}$ of generators are now run on biofuel called "renewable diesel" (mixture of $20 \%$ coconut oil, $80 \%$ diesel with some additives) on 7 outer islands (Koro, Rotuma, Cicia, Vanua Balavu, Gau, Rabi and Lakeba) from 2010. This makes the around $28 \%$ of the diesel generators run on renewable diesel. The renewable diesel price at which FDoE sells to villagers in outer islands is 10-20 cents lower than the diesel price at outer islands [68]. It is worthwhile to note at this point that diesel price at different outer islands is different due to the transportation costs of diesel from mainland to the outer islands. The renewable diesel price has to compete with diesel price at outer islands.

\subsubsection{Wind}


Fiji's experience with wind energy has not been very successful. FEA installed its first and only wind farm of $10 \mathrm{MW}$ capacity in Sigatoka in 2007. It has average annual capacity factor of $7 \%$. This low value can be due to mis-match between the annual wind speed distribution and turbine's power curve. The annual average wind speed for the wind farm site was $5.47 \mathrm{~ms}^{-1}$ while the cut-in and rated wind speed for the turbine is 4 and $12.5 \mathrm{~ms}^{-1}$ respectively [40, 69]. FDoE has not installed any off-grid wind energy conversion systems. However, it has carried out extensive wind monitoring systems over the past years [38]. In 2013, FDoE has been given FJD 0.8 million by GoF to carry out wind monitoring and determine possible wind power locations in Fiji.

\subsection{High cost of RE in Fiji}

Fiji like the other pacific island countries is far from major RE technologies manufacturing countries. The cost of purchasing a particular RE technology is huge due to additional transportation costs and low currency value. Despite a technology being considered "cheap" for developed countries, the cost of buying, installing and commissioning induces huge upfront capital investment. In addition, training or capacity building on the operation and maintenance is needed.

\subsubsection{Installation cost of $R E$}

The cost for different technologies installation cost in Fiji are shown in Table 5. When the size of RE is large, the cost of installation is less. For instance, large hydro installation is the lowest compared to mini hydro. Solar home system, since it is the smallest size it costs more.

\section{Table 5}

Cost of installation of RE technologies.

\begin{tabular}{|l|l|l|}
\hline Technology & $\operatorname{Cost}^{1}(\mathrm{FJD} / \mathrm{kW})$ & Source \\
\hline SHS & 20000 & {$[22]$} \\
\hline GCPV & 13700 & {$[70-71]$} \\
\hline Large Hydro (more than $1.5 \mathrm{MW})$ & 6700 & {$[24]$} \\
\hline Micro hydro (less than $100 \mathrm{~kW})$ & 12600 & {$[72]$} \\
\hline Wind & 3400 & {$[24]$} \\
\hline Biogas & $2500 / \mathrm{m}^{3}$ & {$[67]$} \\
\hline
\end{tabular}

Solar

${ }^{1}$ An exchange rate of 1FJD to 0.53 USD on 25/09/14 was taken. 
According to the data from FDoE, in 2008 the cost per watt of SHS installed on mainland was FJD27 while this decreased to FJD20 in 2012 and 2013 which is a 27\% decrease. For maritime areas the cost is FJD15/W. This cost is low compared to that of mainland installation because for maritime systems each SHS unit size is $270 \mathrm{~W}$ while for mainland systems it is $100-135 \mathrm{~W}$.

Cost of $45 \mathrm{~kW}$ GCPV at the University of the South Pacific is FJD15600/kW [70] and the mini off-grid PV at an island resort is USD6250/kW = FJD11800/kW [71].

\section{Hydro}

FEA installed 42 MW Nadarivatu hydro power scheme in September 2012. The cost of this project was USD3.6 million/MW = FJD6.7million/MW. FDoE installed $30 \mathrm{~kW}$ of micro hydro scheme in Muana, Cakadrove in 1998. This project was funded by Korean government and the cost of project was USD6667/kW. However, this system is not operational since 2005 due to the pipes being damaged by cyclone and community was unable to fund repair costs [65].

\section{Biogas}

The average cost of installing biogas digesters is FJD2600/ $\mathrm{m}^{3}$ which takes approximately one month to install in good weather conditions and 2-4 months in bad weather conditions [67]. The cost increases during bad weather due to labor cost. During good weather the average cost of installation is FJD2000/ $\mathrm{m}^{3}$ while for bad weather it is FJD3000/ $\mathrm{m}^{3}$.

Wind

10 MW wind farm in Sigatoka, Viti Levu was commissioned in 2007 and its cost was FJD3.4million/MW.

\subsubsection{Cost of electricity generation}

Hydro has the lowest cost of electricity generation while wind energy is the highest (Table 6). Dornan and Jotzo [73] have calculated these costs and also determined the future cost of electricity generation from RE technologies by considering the cost reduction shown by the World Energy Outlook (IEA, 2008 [74]). The future costs of generation are based on future RE installation. Bagasse and wind power plant the two technologies whose cost of electricity generation decrease in future with bagasse leading. The cost of electricity generation from new hydro power scheme almost doubles in future. 


\section{Table 6}

Present and future cost of electricity generation [73]

\begin{tabular}{|l|l|l|l|}
\hline Technology & Cost $(\mathrm{FJc} / \mathrm{kWh})$ & & \% change \\
\hline & Present $(2009)$ & Future $(2025)$ & \\
\hline Hydro-power & 19.59 & 32.41 & +65 \\
\hline Oil-power & 38.54 & 41.72 & +8.3 \\
\hline Bagasse & 28 & 17.21 & -39 \\
\hline Sawdust & 23 & 23.44 & +1.9 \\
\hline Wind-power & 92.62 & 73.34 & -21 \\
\hline Solar-power & & 51.59 & \\
\hline Geothermal & & 22.68 & \\
\hline
\end{tabular}

\subsection{Lack of or minimum power sector reform}

Reform in the power sector would lead to increase in competition and private sector participation, resulting in lower generation costs and increase in efficiency where customers would get electricity at a lower price and get better services [75]. Dornan (2014) reports that 13 out of 19 power utilities in Pacific SIDS are government monopolies which are performing poorly [75].

Political situation of a country is one of the factors which determine the success of the power sector reform process. Despite the political upheavals, Fiji has some degree of success in its reform in electricity sector. However, this success has not been to what it was initially planned [75]. There is still low private sector participation in the electricity sector . Currently only two IPPs; FSC and TWIL are generating electricity to sell to grid. However, calling FSC an IPP would be inappropriate as it is also state owned. FEA annual reports from 2005 to 2009 [24] report a number of private investors who have signed power purchase agreement (PPA) with FEA to supply grid electricity (Table 7). However, these developments have not been realized as yet. 


\section{Table 7}

PPA signed by IPPs with FEA [24].

\begin{tabular}{|l|l|}
\hline $\begin{array}{l}\text { Year } \\
\text { Reported }\end{array}$ & Details \\
\hline 2005 & $\begin{array}{l}\text { 250 kW wind power in Malevu. Pacific Free Energy Ltd has signed } \\
\text { PPA with FEA. } \\
5 \mathrm{MW} \text { biomass power plant in Deuba fuelled by woodchips supplied by } \\
\text { Fiji Hardwood Corporation and other sawmills. }\end{array}$ \\
\hline 2007 & $\begin{array}{l}\text { 20 MW biomass power station in Nadi. Tropik Woods Industries Ltd } \\
\text { (TWIL) signed PPA with FEA. }\end{array}$ \\
\hline 2008 & $\begin{array}{l}\text { Elpicon Ltd of Australia signed PPA with FEA to build Hybrid/biomass } \\
\text { power station in Coral Coast. }\end{array}$ \\
\hline $\begin{array}{l}18 \text { MW wood fired biomass power plant near Vuda Point. Pacific } \\
\text { Renewable Energy Ltd signed PPA with FEA. } \\
10 \text { MW waste to energy plant near Sigatoka. IViti Renewable } \\
\text { Development signed PPA with FEA. }\end{array}$ \\
\hline
\end{tabular}

The customer tariff did not change much over past several decades (Fig. 14). Year 2010 saw the largest increase in tariff rate which was $34 \%$ for domestic (residential) customers, $31 \%$ for nondomestic (commercial and industrial) customers that consume up to $14999 \mathrm{kWh}$ and $43 \%$ increase for non-domestic that consumes in excess of $14999 \mathrm{kWh}$. In January 2013, GoF decided to reduce tariff by $5 \%$ for all customers. A gradual increase in tariff over the past decades would have (i) made customers reduce their consumption as well as look into energy conservation and energy efficiency and (ii) decreased the impact of huge cost felt by customers due to the recent increase from 2010. 


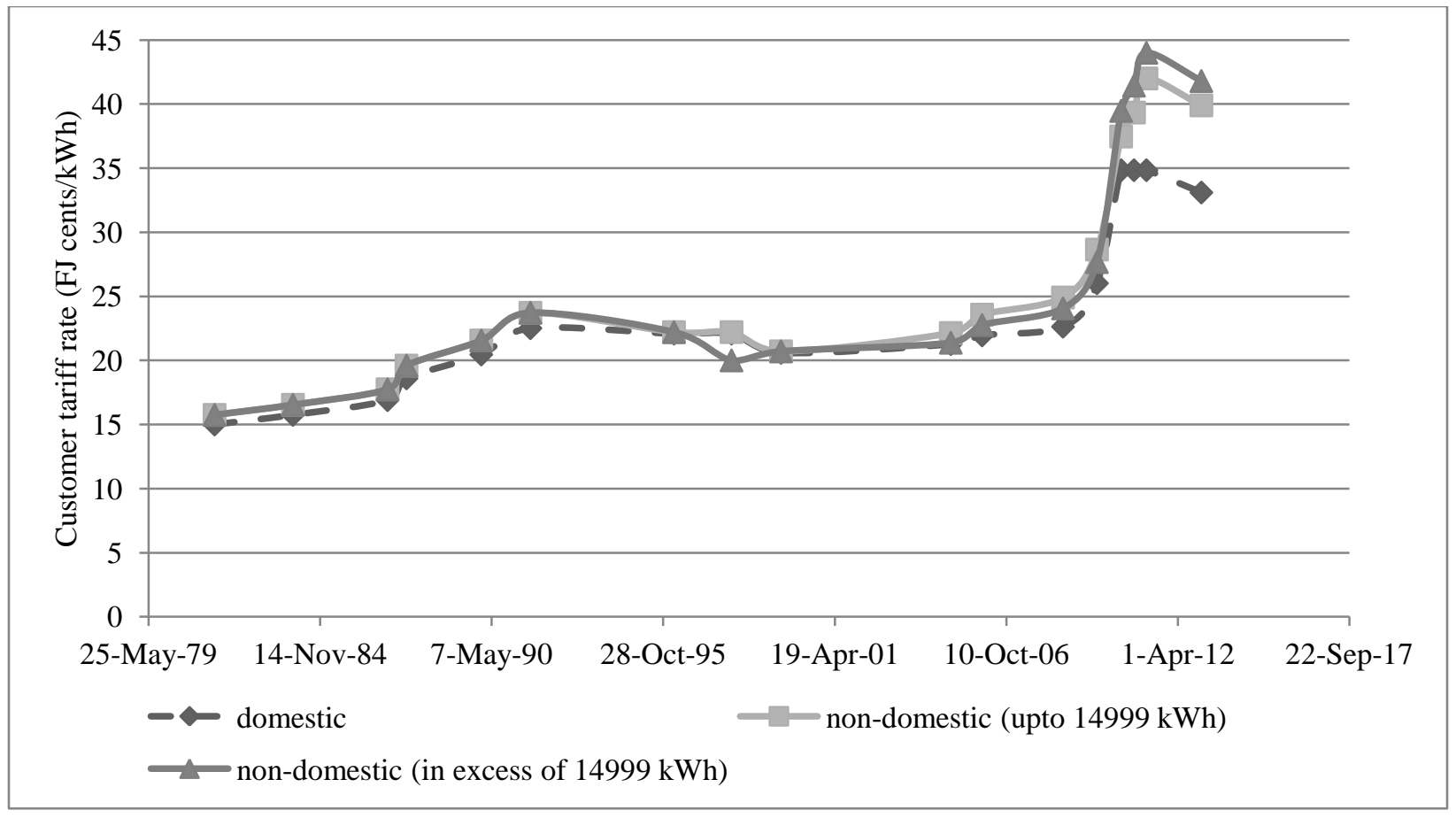

Fig. 14. Historical change in customer tariff rate in Fiji. Data Source: [76].

\subsection{Higher Energy Output Ratio or Energy Intensity}

Rao and Rao [77] have determined energy output ratio (EYR) for various energy sources in Fiji using 1970 to 2005 data. EYR is mega joules (MJ) of a particular fuel to produce one million worth of output, i.e., energy output divided by constant GDP. This is sometimes also called higher energy intensity. They [77] found out that out of unleaded petrol and automotive diesel oil (ADO), unleaded petrol is more efficiently used (mean of $1.395 \mathrm{MJ} /$ million constant factor GDP while ADO has ERY of 2.430). The total energy consumed in Fiji including electricity has an EYR of 7.419 while excluding electricity EYR is 6.809. This high value of EYR indicates Fiji government to consider energy efficiency and conservation.

From 2008 to 2012, FBoS data was analyzed to determine the energy intensity for Fiji. On average, annually $4.22 \mathrm{MJ}$ of energy is consumed (electricity and transport) for every Fijian dollar of GDP. Fig. 15 shows the variation of energy intensity (energy consumption per GDP at current basic price of 2008) over the past 5 years. FBoS provided data on mineral fuel import and re-export. The retained import on mineral fuel was determined and then for different transport fuels the volume and mass of fuels were converted to energy value using lower heating values (LHV) for different fuels. The LHV was obtained from the energy statistics manual [78]. 


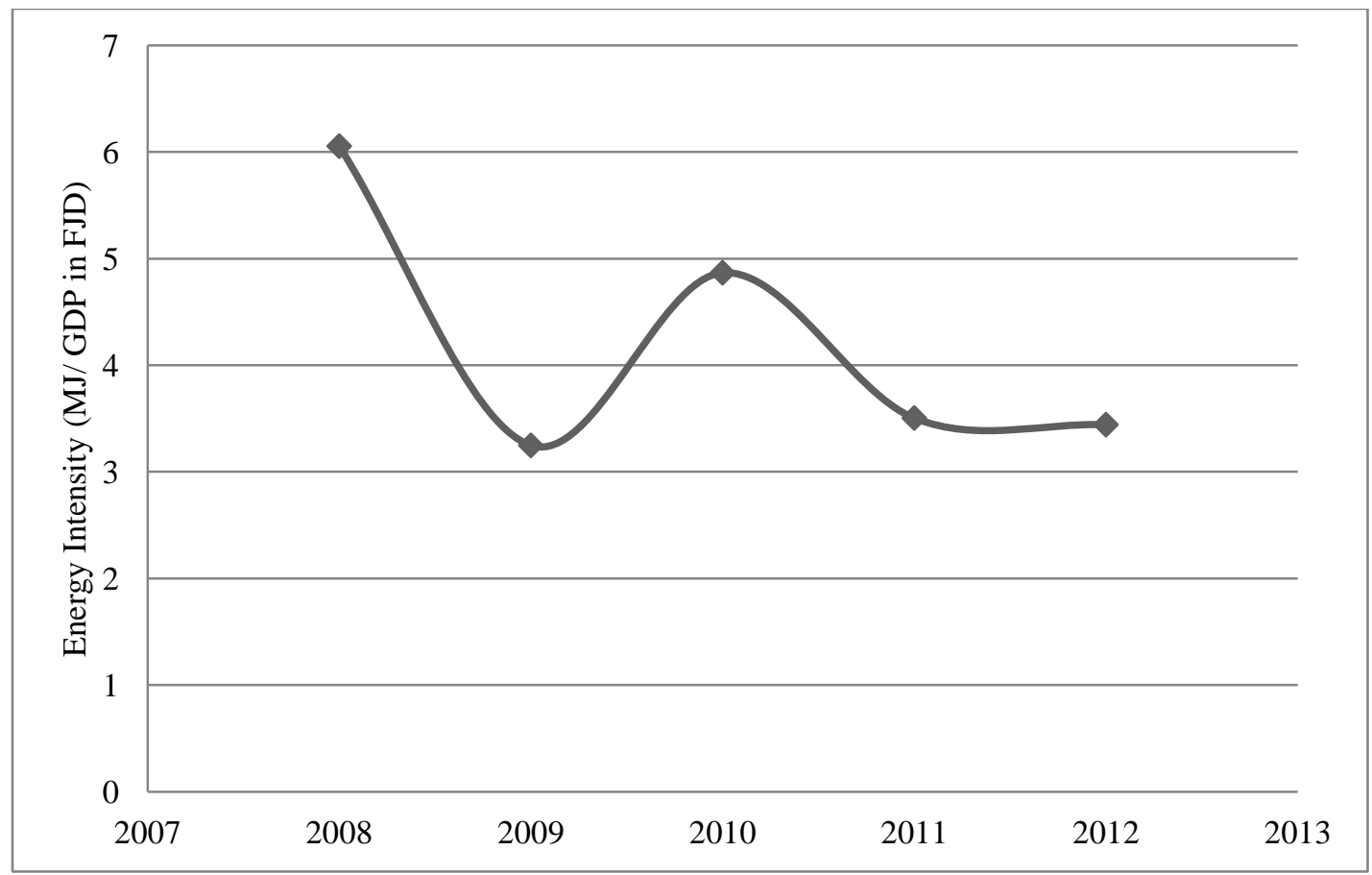

Fig. 15. Energy intensity in electricity and transport fuel consumption in Fiji over past 5 years.

Considering Fig. 15, the energy intensity over the past 5 years is decreasing. One reason for this decrease can be due to the increasing electricity price to consumers. Another factor can be the introduction of standards and labeling for refrigerators and freezers from June 2011. From 2010 to 2011 there was a $3.05 \%$ decrease in electricity consumption while from 2011 to 2012 there was a $1.24 \%$ decrease.

Despite this measure, there is still room for improvement. More standards and labels must be available for electrical equipment so that it operates efficiently. In addition, consumer behavior has to change in order to reduce their energy consumption.

\subsection{External aid in energy sector}

Due to the small economy and limited financial and technical resources for capital investment in off-grid renewable energy and energy efficiency projects are restricted. This creates a need for external aid. Niles and Lloyd [79] emphasize that growth in energy technologies in SIDS for producing energy is possible with external aid as indigenous government do not have budget to invest in renewable energy or energy efficiency capital intensive projects.

From 2012 to 2014 in Fiji, projects concerning solar PV have received external funds totaling of USD2.334 million [80]. Funds have also been received in the past to carry out low carbon tourism in Fiji and for review of the national energy policy. In energy efficiency, fund was provided to promote cycles to reduce carbon emissions and congestion on roads and also for 
standards and labeling. There were support provided for capacity building of staff from utilities as well as "train the trainers" for off-grid solar PV. Assistance is also provided in organization, providing reports or assessments on how options available for increasing RE in power and transport sector, how to improve bulk procurement of fuel, quarterly report on fuel price market and what other energy option are there for Fiji and Pacific. In addition, there are some funds which have to be shared with other PICs.

\subsection{Strategies}

Measures taken on the challenges presented in the previous section would ensure sustainable development of energy in Fiji as SIDS. Considering the escalating fossil fuel cost and transportation cost of fuel to remote outer islands, Fiji's best option is to invest in RE and EE technology. In addition, to increase FEA's percentage of RE electricity generation, IPP contribution to grid must increase. However, for RE to be successful, energy needs to be used efficiently and conservatively. The following sub-sections discuss how this can be achieved with SWOT (Strengths, Weaknesses, Opportunities, Threats) analysis done for every strategy, Table 9. SWOT analysis can assist in decision making on which strategy to prioritize. SWOT assists in building the strengths of the strategy, addressing the weaknesses, considering the opportunities available for a particular strategy and guarding against the threats. Strengths and weaknesses are internal factors which can be controlled while opportunities and threats are external factors.

\subsection{Increase public-private partnership (PPP).}

Increase public-private sector partnership to ensure growth in EE and RE market in Fiji. This partnership would ensure that the government provide legislations and policy to promote the RE and $\mathrm{EE}$ and private sector to provide technical expertise, finance sector for providing financing even though these projects are high risk, the educational sector to provide training and skills development for operation and maintenance of RE and EE projects. These partnerships would guarantee a whole-sector approach where all stakeholders are involved. Everyone involved would have some portion of their time/money/human resources/land invested in $\mathrm{EE}$ and $\mathrm{RE}$ projects to ensure that it succeeds and there can be accelerated feedbacks and project accepted readily. The risks in RE or EE projects would be shared by all stakeholders.

Due to dispersed islands in Fiji, distributed generation is often used, hence, pro-poor publicprivate partnership (5P) model can be adopted for guaranteeing the success of RE and EE in remote areas. In 5P model poor communities or remote/rural islands and villages are not only customers that receive the benefits but are also partners in business ventures [81]. In 5P model private sector involves local development banks, equipment manufacturers, energy service company (ESCO), philanthropic organizations, Central Business Organization (CBO), cooperatives and households themselves to increase the access to modern energy forms [81]. 

Sovacool [81] to expand the energy access to poor communities. To achieve self-sustaining market of RE in rural communities there should be stringent technical standards for equipment, fines for business providing low standards equipment, phased grants provided to ESCO, and training for communities and women. Klitenberg et al. [56] stresses that involving the end users of $\mathrm{RE}$ or $\mathrm{EE}$ project from the beginning would ensure project meeting the requirement of consumers and in return consumers are aware and understand the operation of the system and its limitation.

\subsection{Set-up risk mitigation facilities}

$\mathrm{RE}$ and EE projects are perceived as high risk with regards to technology and cash flows by finance institutions. Parthan et al. [82] reports that absence of risk mitigation facilities in developing countries is constraining the flow of private finance to low-carbon energy investments. Agrawal [83] discusses a broad range (from standard insurance cover to judicious selection of project attributes) of mitigation strategies for RE project financing. This strategy can be adopted in Fiji where insurance is provided for RE projects which covers natural disasters. Past resource data (wind or solar) can be studied to ensure reduction in resource supply risk for energy conversion. In addition, for biomass resource, long-term contracts with resource suppliers should reduce resource risk. A good reputed and bankable contractor for construction minimizes the risks that project might not meet its specifications. Policies and an incentive framework reduce the risk RE and EE market development.

Wulfinghoff [84] presents 10 questions which need to be answered to decide whether a particular $\mathrm{RE}$ or EE project would succeed. The first and most important is determining the energy return ratio (ERR) (energy output to energy input) of the project; this ratio does not only consider the finance involved but also the energy required for manufacturing and installing the equipment and the energy needed to support the workers who produced the materials and during construction phase. He [84] informs that for a RE or EE project to be attractive ERR has to be minimum of $3: 1$ or $5: 1$. Out of 10 questions, another three questions are very relevant to SIDS:

1. How close to reality is it? Technologies introduced in SIDS must be well proven. Anything less would prove to be a risky project where investors are not willing to participate.

2. Can it work well in our location? Introduction of a technology which has been successful in other developed countries may not be favorable in SIDS. Factors such the availability of finance, technical expertise and geography for the implementation of RE or EE project need to be considered.

3. Is the technology needed by the community? Before introduction of any RE or EE technology in a community, needs analysis must be carried out. 

community involved, that is, capacity building of stakeholders involved. Capacity building for all stakeholders can be carried out by the donor agency which sets up the RE or EE project or by GoF. Trainers in Fiji, need to trained for skills and knowledge in operation and maintenance of RE or EE systems, to provide more frequent training of communities. Trainers can also provide "refresher" training for communities on a regular basis. Once, communities involved are educated on the operation, maintenance and the cost of maintenance, they would be better prepared when RE or EE system shuts down due to some kind of damage. Capacity building on setting up and managing a finance scheme for maintenance of RE or EE can minimize the risk of failure of RE or EE system. With this knowledge communities can set-up some kind of business in the village to produce and maintain funds for maintenance.

The above paragraph leads to the concept of monitoring of RE and EE projects. For off-grid RE distribution, the FDoE monitors and provides support for the first 3 years. After this period, the recipient villages are the "owners" of the system and are responsible for the operation and maintenance of the system. However, there have been glitches in maintenance of RE system. Having a facility or section in FDoE that does proper and timely monitoring of every RE and EE system and provide necessary advise would remove or minimize the risk of failure.

Land is a sensitive issue in Fiji and before initiation of RE or EE project it must be ensured that some kind of memorandum of understanding or agreement is reached between the land owners and investors. Land owners must be compensated to avoid misunderstanding between stakeholders when the project has been commissioned.

In addition, due to geographic isolation of Fiji from the developed countries, cost of bringing RE or EE technologies in country can be quite significant in term of both finance and time. It is imperative that there should be duties or taxes removed or minimized from importing RE or EE products or equipment. See section 5.7 for details on what government of Fiji (GoF) is currently doing.

\subsection{Change customer behavior}

It takes a great deal to change the behavior of customers in regards to their energy use and consumption. However, two important factors are fuel price or electricity price and standards on electrical appliances, fuel and vehicles to promote EE and conservation have significant impact on consumption.

Households: It is noticed that as the income level and social status of households increase, their energy consumption increase. One way to change the behavior is through electricity price which customers pay. Secondly, more standards on electrical appliances would ensure that only energy 


\subsection{Credible Feed-in-tariff (FiT) structure for IPP}

Introduction of feed-in-tariff (FiT) in earlier years and then renewable energy portfolio standards (REPS) in following years would boost investment in RE and EE sector for electricity generation and make an attractive niche for RE and EE market development. Currently, in Fiji there is no structure for feed-in-tariff (FiT) for electricity generated from different sources of electricity and in the different locations. Fiji Commerce Commission [89] reports that the new minimum IPP tariff rate is 25.65 Fijian cents/kWh. This was then re-evaluated in May 2014 to 33.08 Fijian cents $\mathrm{VEP} / \mathrm{kWh}$ [90]. This new rate is expected to boost IPP investment.

\subsection{Develop locally owned business in RE and EE technology}



procurement done from "overseas". When there is business operating locally which sells equipment and services for renewable energy and energy efficiency, customers do not have difficulty in obtaining replacement parts or do not have to look faraway to purchase EE products. Local business making and selling affordable, durable and efficient wood stoves to rural area customers would boost energy efficiency in cooking stoves and improve lifestyles.

Providing funding to energy service companies (ESCO) would ensure their development and success of distributed renewable energy generation [82]. Conversing with FDoE personnel, it became clear that there is local expertise to install and maintain SHS, however, for hydro power; there are very few businesses who are experts. Usually, there are civil works businesses that are given the job to repair an off-grid damaged hydropower system. Hence, existence of ESCO which specialize in different RE and EE technology would minimize the chance of failure.

\subsection{Strengthen the institutions supporting energy sector}

The energy institutions in Fiji (Table 8), are responsible for energy planning, energy policy making, energy project financing, determination of energy prices (electricity tariff and fuel prices) and energy research. These institutions need to be well financed and adequately staffed to carry out its responsibilities effectively. In 2013, for renewable energy infrastructure development FJD19.4 million work of external aid was given. This aid either has been in kind or cash.

Using external aid (German Technical Cooperation (GIZ) - Deutsche Gesellschaft fur Internationale Zusammenarbeit and United Nations Development Programme (UNDP)), Fiji has been able to successfully review National Energy Policy for Fiji which acts as a guideline for the goals and objects to achieve by 2030 . The access to modern energy to rural or remote islands and villages in Fiji is made possible by external aid; namely Chinese, Japanese, US, Korean, Turkish governments, to name a few. The technologies and expertise is provided by external aid. This assists GoF to install and commission renewable energy projects.

In addition, GoF should allocate more accountable budget for RE and EE development in Fiji to cater for initiation, implementation, construction, capacity building, and monitoring of these projects. This enables a high rate of success. 


\section{Table 8}

Energy institutions in Fiji. Source: [91]

\begin{tabular}{|c|c|}
\hline Institution & Energy Activity \\
\hline \multicolumn{2}{|l|}{ Government } \\
\hline Fiji Department of Energy, FDoE & $\begin{array}{l}\text { Responsible for energy policies and plans, energy efficiency } \\
\text { and conservation, renewable energy (RE) and rural } \\
\text { electrification. Overall coordination of all energy related } \\
\text { activities. }\end{array}$ \\
\hline Fiji Electricity Authority, FEA & $\begin{array}{l}\text { Responsible for generation, transmission and distribution of } \\
\text { grid electricity. It plans the national grid. }\end{array}$ \\
\hline $\begin{array}{l}\text { Ministry of Public Enterprises \& } \\
\text { Public Sector Reform }\end{array}$ & $\begin{array}{l}\text { Overseas business performance of FEA as a state owned } \\
\text { enterprise. It also scrutinizes FEA's corporate plan and } \\
\text { statement of corporate intent. }\end{array}$ \\
\hline Fiji Commerce Commission & $\begin{array}{l}\text { Economic regulation of the energy sector, including } \\
\text { competition regulation and setting of fuel and electricity } \\
\text { prices. }\end{array}$ \\
\hline Prices and Income Board & $\begin{array}{l}\text { Regulates wholesale and retail prices of motor spirit (also } \\
\text { called gasoline or petrol), kerosene and automotive diesel oil } \\
\text { (ADO) and influences to some extent the technical } \\
\text { specification of fuels. }\end{array}$ \\
\hline $\begin{array}{l}\text { Ministry of Finance and National } \\
\text { Planning, MoF }\end{array}$ & $\begin{array}{l}\text { Responsible for planning and monitoring of energy budget } \\
\text { for policy implementation and establishing and enforcing } \\
\text { maximum petroleum fuel prices. }\end{array}$ \\
\hline \multicolumn{2}{|l|}{ Non-Government } \\
\hline $\begin{array}{l}\text { Multilateral Agencies such as } \\
\text { SPC, IRENA, Forum Secretariat, } \\
\text { ADB, GEF. }\end{array}$ & $\begin{array}{l}\text { Responsible for providing funding for energy related } \\
\text { projects. Also provides their technical expertise. }\end{array}$ \\
\hline $\begin{array}{l}\text { Bilateral agencies such as } \\
\text { AusAid, NZAid, JICA, KOICA, } \\
\text { etc. }\end{array}$ & $\begin{array}{l}\text { Provides funding for energy related projects. Also provides } \\
\text { their technical expertise. }\end{array}$ \\
\hline $\begin{array}{l}\text { Educational Institutions such as } \\
\text { USP, FNU and UoF }\end{array}$ & Responsible for carrying out research in energy. \\
\hline
\end{tabular}

Currently for electricity tariff the regulators are FEA and Fiji Commerce Commission. However, FEA is in conflict to decide the tariff which IPP should be paid. GoF is working towards making Fiji DoE the regulator, to increase the share of IPP is grid electricity supply [41].

\subsection{Fijian government initiative to reduce fossil fuel import}


GoF has allocated FJD 1 million towards the Somosomo Hydro Project [92]. To promote greener environment and to reduce dependence on imported fossil fuel "Green Tax" has been introduced from 2013. In this tax users to pay an extra Fijian 2 cents for every litre of imported fossil fuel consumed except kerosene, pre-mix and white benzene [92]. However, this tax will not be applicable to public transportation such as bus industry, inter-island vessels and fishing so that these consumers are not burdened with this additional cost.

GoF has also allocated FJD 2.5 million for bio-diesel plants set up in smaller islands. In addition, FJD0.858 million has been allocated to purchase biofuel testing equipment. GoF is also providing 10 year tax holiday for bio-fuel production in Fiji from agricultural commodities into biofuel, duty free importation of plants, machinery and equipment for initial set-up and duty free importation on chemicals required for biofuel production [86]. FJD0.2 million has been set aside for biogas projects [87]. FJD0.4 million has been given to carry out feasibility study of wind, solar, hydro, biomass and geothermal and FJD 8.5 million allocated to grid extension to remote areas in two main islands. This corresponds to a total of FJD12.5 million for use in 2014. For 2013, in 2012 budget FJD 6.5 million was budgeted for renewable energy development projects and FJD8.5 million was budgeted for rural electrification [93].

Duty concessions are in place for purchase of renewable energy technologies. The Reserve Bank of Fiji's (RBF) Import Substitution and Export Finance Facility (ISEFF) was set up to improve Fiji's balance of payment position by assisting exporters, large scale commercial agricultural farming and renewable energy businesses to obtain credit at concessional interest rates [93]. In 2012, FJD2.7 million was used for renewable and sustainable energy funding.

\section{Table 9}

SWOT analysis of energy strategies

\begin{tabular}{|c|c|}
\hline \multicolumn{2}{|c|}{ SWOT analysis of Pro-poor public-private partnerships (5P) in Fiji } \\
\hline $\begin{array}{l}\text { - Strengths } \\
\text { PPPs exist for SHS; ESCOs provide } \\
\text { maintenance work. } \\
\text { - Fiji Development Bank and ANZ bank } \\
\text { are offering loans for sustainable } \\
\text { energy projects with WB providing } 50 \\
\% \text { guarantee. This is under the } \\
\text { Sustainable Energy Financing Project } \\
\text { (SEFP). } \\
\text { FDoE provides training to villagers on } \\
\text { operation and maintenance of } \\
\text { distributed generators. }\end{array}$ & $\begin{array}{l}\text { Weaknesses } \\
\text { - Does not have PPP for small hydro, } \\
\text { biogas, and other distributed generation } \\
\text { systems apart from solar. } \\
\text { - Uptake of loans under SEFP is low as } \\
\text { remote island customers do not have } \\
\text { good credit rating to give the remaining } \\
50 \% \text { guarantee [94]. } \\
\text { - Technical standards for RE and EE } \\
\text { equipment do not exist. } \\
\text { - There are no penalties for supplying } \\
\text { low grade/standard equipment. } \\
\text { Villagers not trained in managing } \\
\text { maintenance funds. }\end{array}$ \\
\hline $\begin{array}{l}\text { Opportunities } \\
\text { - Outer island populations are now }\end{array}$ & - Low number of customers for RE and \\
\hline
\end{tabular}


interested in renewable distributed generation.

- Funds are available from nongovernment organization as well as from AusAid, EU and other governments for installation of RE and EE projects.

- Competency standards are being developed for RE installers and designers

- A number of initiatives are targeting human capacity development

- The support from the Green Climate Fund (GCF) facility will help develop more RE/EE projects.
EE in outer islands. At times, it may not be appealing to potential business.

- Extra shipping costs involved in transportation to outer islands

- Frequent cyclones might damage RE installations

- Climate change impacts such as reduced rain fall and more intense cyclones affect the RE projects negatively

- Consumers in remote locations do not have enough income to pay for energy services.

\section{SWOT analysis of changing customer behaviour}

\section{$\underline{\text { Strengths }}$}

- FDoE has standards on importation of refrigerators. They also have energy usage labels (or energy star rating) on TV, PCs, fridge, washing machine for customers to make the right choice.

- FDoE do public awareness on energy conservation and energy efficiency via media as well as running competitions for industries and schools so that young generation is also aware.

- Upcoming building codes.

- Penalties exist for retailers who do not follow the standards and labeling program from FDoE.

\section{Opportunities}

- National policy document supports EE and changing customer behavior.

\section{Threats}

- Standards for other electrical appliances are still to come out.

\section{SWOT analysis of FiT}

Strengths

- Electricity exported to the grid will be paid FJD 0.3308.

- FDoE willing to formulate IPP investment framework to increase RE based electricity generation [94].

\section{Weaknesses}

- Fiji does not have technology specific tariff.

- Non-existence of effective IPP framework to boost investment in RE based power generation [94]. 


\subsection{Conclusions}

This comprehensive study presents the state of affairs of Fiji's energy situation and the SWOT analysis will help develop pathways for Fiji's sustainable development. Fiji is characterized by its smallness, remoteness, lack of technical expertise on maintenance of RE systems and high dependence on imported fossil fuels. Due to a tropical island country, Fiji has vast renewable energy resources but no fossil fuel reserves. In 2012, hydro power dominated (64\%) the grid electricity generation. $89 \%$ of household in Fiji have access to electricity. The electricity generation and consumption growth rate on average is $4 \%$ annually. The non-domestic customers are consuming $70 \%$ of the grid-electricity.

All fossil fuel is imported in Fiji and then some of it is re-exported to Pacific Island countries. Out of the total retained import, mineral products import takes up $21 \%$. The year 2008 saw the highest mineral fuel import bill of FJD1.2 billion when there was global oil price hike while 

the past 14 years, the annual average volume of jet fuel and diesel imported in Fiji is 125 and 360 million litres with $16 \times 10^{6} \mathrm{~kg}$ of LPG where on average petroleum and diesel oil and jet fuel makes up $90 \%$ of fuel import bill.

One of salient features on fossil fuel import bill is that over the past 4 years is that it takes up on annual average of $40 \%$ of the total export and tourism industry earnings which is threatening to Fiji's economy. Dispersed islands lead to the challenge of accessibility and affordability of modern fuels to remote areas or outer islands. Wood open fire is most popular source of cooking in rural areas whereas LPG dominates in urban areas. Slow growth in RE sector is also a challenge. Reason for this is the huge upfront capital cost. By 2025, electricity generation cost from bagasse is the lowest with a value of FJ17.21 cents/kWh. Hence, it may be in FSC's interest to increase their generation capacity. Minimum power sector reform has led to low or negligible IPP. Potential IPP's have signed PPA with FEA; however, these projects have not been realized. Minimum power sector reform has also led to stagnant customer tariff rates from 1990 to 2005, resulting in increased electricity consumption and customers having no regard to energy efficiency or conservation. Currently, energy intensity is 4.22 MJ/GDP dollar which can be lowered by using energy more efficiently in production. In addition, Fiji has to complete with other PICs to get external aid since in some cases external aid is shared with other PICs.

Since, Fiji is completely dependent on imported fossil fuels for its transportation needs and $33 \%$ dependent on electricity generation, it has to import despite increasing costs. In addition, it cannot control the global prices. To overcome challenges in energy sector, Fiji needs to come up with strategies. To reduce dependence on fossil fuel, RE needs to be promoted and for this public-private partnership needs to be strengthened, risk mitigation facilities need to be established and institutions supporting energy sector must be strengthened. IPP tariff rate needs to be revised by considering the cost of generation from different sources. This rate needs to profitable for IPP to foster increase in IPP share in grid electricity supply. In addition, GOF has introduced tax incentives such as duty free on importation of RE and EE equipment, import of LPG vehicles is duty free and biofuel production tax incentives. For RE to be successful and to raise energy efficiency and conservation, customer behavior needs to be changed and locally owned business in RE and EE have to be developed.

\section{Acknowledgements}

Authors would like to sincerely thank Fiji Bureau of Statistics for providing the data for analysis and Fiji Department of Energy for providing information on rural electrification. 


\section{References}

[1] Bhattacharyya, SC. Energy access programmes and sustainable development: A critical review and analysis. Energy for Sustainable Development 2012; 16:260-71.

[2] United Nations Framework Conventions on Climate Change (UNFCCC). 2005. Climate change: Small island developing states. Climate Change Secretariat, Germany. http://unfccc.int/resource/docs/publications/cc_sids.pdf [Accessed: 17/07/14].

[3] Pacific Lighthouses,

http://www.irena.org/menu/index.aspx?mnu=Subcat\&PriMenuID=36\&CatID=141\&Subc

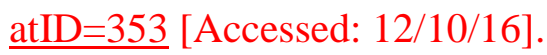

[4] Pacific Regional Information System (PRISM), http://www.spc.int/prism/

[5] Fiji Commerce Commission. Final determination of electricity tariff rates: Fiji Electricity Authority. Date Issue 11 Dec 2012. http://www.commcomm.gov.fj/ [Accessed: 02/09/13].

[6] http://www.ppa.org.fj/wp-content/uploads/2013/09/Benchmaking-Report-2012-Final.pdf [Accessed: 12/10/16].

[7] Fiji Bureau of Statistics, Key Statistics. 1975-2013. Government of Fiji Print. Suva Fiji.

[8] Fiji Bureau of Statistics, http://www.statsfiji.gov.fj/ [Accessed: 16/10/14].

[9] Fiji Bureau of Statistics. Electricity Access Data. Personal Communication to Nokelevu, K. (A. Assistant Statistician), Household Survey Unit on 05/11/14.

[10] Secretariat of the Pacific Community. Country energy security indicator profile 2009: Fiji. SPC 2012 Suva, Fiji. ISBN: 978-982-00-0547-1

[11] Fiji Bureau of Statistics. Household cooking fuel. Personal Communication to Tubanaika, S., Household Survey Unit on 13/08/14.

[12] United Nations ESCAP. Statistical yearbook for Asia and the Pacific 2012. Table II.9. 6 November 2012. http://www.unescap.org/stat/data/syb2012/ [Accessed: 25/07/14].

[13] http://www4.unfccc.int/ndcregistry/PublishedDocuments/Fiji\%20First/FIJI_iNDC_Final 051115.pdf [Accessed: 13/10/16].

[14] European Commission. A green growth framework for Fiji: Restoring the balance in development that is sustainable for our future (2014). http://capacity4dev.ec.europa.eu/intra-acp_gcca/document/green-growth-framework-fijirestoring-balance-development-sustainable-our-future-2014 [Accessed: 13/10/16].

[15] http://prdrse4all.spc.int/ [Accessed: 13/10/16].

[16] Fiji Island Bureau of Statistics. Poverty and household incomes in Fiji in 2008-09: 200809 Household income and expenditure survey results. By Narsey W, Raikoti T, Waqavonovono E. September 2010. Fiji. 
[17] United Nations Educational, Scientific and Cultural Organization (UNESCO). Migration issues in the Asia Pacific: Issues paper from Fiji. http://www.unesco.org/most/apmrnwp6.htm [Accessed: 05/11/14].

[19] http://devpolicy.org/economic-growth-investment-confidence-and-poverty-reduction-infiji-semi-rational-exuberance-20130919/ [Accessed: 17/10/13].

[20] Ministry of Tourism. Tourism performance 2012. Republic of Fiji. http://dtxtq4w60xqpw.cloudfront.net/sites/all/files/pdf/fiji_tourism_performance_2012_r eport_0.pdf [Accessed: 11/11/14].

[21] Fiji Bureau of Statistics. Tourism earnings (FJD million). http://www.statsfiji.gov.fj/index.php/migration-a-tourism/10-migrationstatistics/migration-a-tourism/118-tourism-earnings-fjd-million [Accessed: 11/11/14].

[22] Fiji Department of Energy. Solar home systems, solar lights and solar water pumps. Personal Communication to Valemei, J. Rural Electrification Unit on 14/08/14.

[23] Asia Sustainable and Alternative Energy Program. Wind energy resource atlas. https://www.astae.net/content/wind-energy-resource-atlas [Accessed: 29/07/14].

[24] Fiji Electricity Authority, Annual Report 2003-2013. http://www.fea.com.fj/ [Accessed: 30/04/15].

[25] Fiji Department of Energy. Fiji's hydro potential report volume: 1995-2006. 2009. http://www.fdoe.gov.fj/images/Renewable_Energy/hydro\%20potential\%20report.pdf [Accessed: 01/10/13].

[26] United Nations Industrial Development Organization (UNIDO) and International Center on Small Hydro Power (ICSHP). 2013. World small hydropower development report 2013: http://www.smallhydroworld.org/fileadmin/user_upload/pdf/Oceania_PICT/WSHPDR_2 013_Fiji.pdf [Accessed: 24/09/14].

[27] Belena, M. Hydro power development in Fiji. Symposium on Renewable Energy Technologies, 6-8 ${ }^{\text {th }}$ October, 2011, Suva, Fiji.

[28] A. Cokanasiga, Ministry of Fisheries and Forests, Fiji, pers comm. on 14/05/14

[29] Fiji Department of Forests. Log production. Personal communication to Tabaiwalu, M. at Suva Headquarters on 22/10/14.

[30] Fiji Department of Forests. Sawmill production. Pers. Communication to Wainiqolo, S. at Nasinu on 08/10/14.

[31] The Fiji Sugar Corporation Limited. Annual Report 2011. http://www.fsc.com.fj/DOC/2011_Annual_Report1.pdf [Accessed: 12/11/13].

[32] \$24 million wood co-generation in Fiji. http://fridayoffcuts.com/dsp_article.cfm?id=271\&aid=2113 [Accessed: 13/11/13].

[33] REEEP Policy Database, Fiji Islands 2012. http://www.reep.org/policy-database [Accessed: 18/10/13]. 
[34] The Fijian sugar industry: Investing in sustainable technology. Oxfam briefing paper. 77. http://archives.pireport.org/archive/2005/October/FIJI\%20SUGAR\%20INDUSTRY\%20 REPORT\%20-\%20OXFAM.pdf [Accessed: 18/11/13].

[35] McCoy-West AJ, Milicich S, Robinson T, Bignall G, Harvey CC. Geothermal resources in the Pacific Islands: The potential of power generation to benefit indigenous communities. Proceedings, $36^{\text {th }}$ Workshop on Geothermal Reservoir Engineering; Jan 31Feb 2 2011, Stanford University, Stanford, California. https://pangea.stanford.edu/ERE/pdf/IGAstandard/SGW/2011/mccoy.pdf [Accessed: 24/09/14].

[36] McCoy-West AJ, Bignall G, Harvey CC. 2009. Geothermal Power Potential of Selected Pacific Nations, GNS Science Consultancy Report 2009/180 101p. http://www.edinenergy.org/pdfs/geothermal_potential.pdf [Accessed: 24/09/14].

[37] Fiji Department of Energy. SE4All Report. www.fdoe.com [Accessed: 03/10/14].

[38] Asmundsson RK. 2008. South Pacific Islands - Geothermal energy for electricity production. International Development Agency. http://www.edinenergy.org/pdfs/pacific_islands_geothermal.pdf [Accessed: 24/09/14].

[39] Datt H. IRENA: Fiji has potential in geothermal energy. FijiOne Television. http://fijione.tv/irena-fiji-has-potential-in-geothermal-energy/ [Accessed: 24/09/14].

[40] Fiji Electricity Authority. http://www.fea.com.fj/ [Accessed: 22/07/14].

[41] Department of Energy. Draft energy policy 2013. www.fdoe.gov.fj [Accessed: 26/09/13].

[42] Narsey W. Poverty in Fiji: Changes 2002-03 to 2008-09 and policy implications. Fiji Islands Bureau of Statistics. May 2012.

[43] Fiji Electricity Authority. FEA customers. Personal communication to Narayan, A on 29/06/12.

[44] Fiji Bureau of Statistics. Electricity Data. Personal communication to Keleinavutoka, T. on $03 / 10 / 13$.

[45] Narayan PK, Narayan S, Prasad A. Understanding the oil price-exchange rate nexus for the Fiji Islands. Energy Economics 2008; 30: 2686-96.

[46] Macrotrends. Crude oil price history chart. http://www.macrotrends.net/1369/crude-oilprice-history-chart [Accessed: 12/09/14].

[47] Fiji Bureau of Statistics. Mineral fuel data. Personal communication to Lilieta L on 30/06/14.

[48] Fiji Bureau of Statistics, Statistical News, Release No: 26, $20142^{\text {nd }}$ May 2014.

[49] Herold, A. Comparison of $\mathrm{CO}_{2}$ emission factors for fuels used in greenhouse gas inventories and consequences for monitoring and reporting under the EC emissions trading scheme. The European Topic Centre on Air and Climate Change (ETC/ACC) $\begin{array}{llll}\text { Technical } & \text { Paper } & 2003 / 10 . & \text { Jul. }\end{array}$ http://acm.eionet.europa.eu/docs/ETCACC_TechnPaper_2003_10_CO2_EF_fuels.pdf [Accessed: 10/04/15]. 
[50] Fiji Department of Energy. Energy conservation and efficiency. http://www.fdoe.gov.fj/images/PDF/public_notice2014.pdf [Accessed: 12/08/14].

[51] Fiji Department of Energy. Energy efficiency into the national building code. www.fdoe.gov.fj/images/Energy_Efficiency/phase1_report.pdf [Accessed: 12/08/14].

[52] Kumar R, Vuniyayaywa V. Climate, climate variability and change of Fiji Islands. Pacific Climate Change Science Program. International Climate Change Adaptation Initiative. http://www.pacificclimatechangescience.org/wp-content/uploads/2013/10/3.Fiji-GH-Poster.pdf [Accessed: 20/04/15].

[53] http://www.pacificclimatechangescience.org/wpcontent/uploads/2013/06/PCCSP_Vol2_Ch5_Fiji.pdf [Accessed: 20/04/15].

[54] Dornan M. Solar-based rural electrification policy design: The renewable energy service company (RESCO) model in Fiji. Renewable Energy 2011; 36: 797-803.

[55] Urmee T, Harries D. The solar home PV program in Fiji - A successful RESCO approach? Renewable Energy 2012; 48: 499-506.

[56] Klintenberg P, Wallin F, Azimoh LC. Successful technology transfer: What does it take? Applied Energy 2014; In Press, http://dx.doi.org/10.1016/j.apenergy.2012.01.087 [Accessed: 17/07/14].

[57] Fiji Department of Energy. Diesel capacity and fuel usage. Banivanua, V. Personal communication on 03/09/14.

[58] The Jet. Mar. 2014. Grid tied solar resort: A first for Fiji. http://thejetnewspaper.com/2014/03/26/grid-tied-solar-resort-a-first-for-fiji/ [Accessed: 25/09/14].

[59] Sunergise. World's largest solar installation a marina upsizes again. http://www.sunergisegroup.com/worlds-largest-solar-installation-at-a-marina-upsizesagain/ [Accessed: 25/09/14].

[60] MaiLife. The first solar power supermarket in Fiji. http://www.mailife.com.fj/the-firstsolar-powered-supermarket-in-fiji/ [Accessed: 25/09/14].

[61] Fiji Sun Online. MarkOne becomes first apparel firm in the islands to go solar. http://fijisun.com.fj/2014/09/17/mark-one-becomes-first-apparel-firm-in-the-islands-togo-solar/ [Accessed: 25/09/14].

[62] The Jet. Rooster poultry goes solar. http://thejetnewspaper.com/2014/05/03/roosterpoultry-goes-solar/ [Accessed: 25/09/14].

[63] Fiji Sun Online. Turtle island resort installs 968 solar panels. http://www.fijisun.com.fj/2013/03/19/turtle-island-resort-installs-968-solar-panels/ [Accessed: 28/10/14].

[64] Clay Energy. Case study: Taveuni home power systems. http://www.clayenergy.com.fj/case-study [Accessed: 25/09/14].

[65] Fiji Department of Energy. Micro and Mini Hydro Systems. Personal Communication to Paula Katirewa, Senior Scientific Officer on 08/08/14. 
[66] Naimawi B. Fiji Electricity Authority. Facilitating the development of a resourceefficient cost effective and environmentally sustainable energy sector. Presentation at National Energy Forum. $4^{\text {th }}$ April 2013. http://www.fdoe.gov.fj/ [Accessed: 26/09/13].

[67] Fiji Department of Energy. Biogas. Personal Communication to Delaimoala, J. on 14/08/14.

[68] Fiji Department of Energy. Biofuel Unit. Personal communication to Jeke Pai (biofuel engineer) on 14/04/15].

[69] The Wind Power - Wind Turbines and Wind Farms Database. Vergnet GEV MP 275/32. http://www.thewindpower.net/turbine_technical_en_88_vergnet_gev-mp-275-32.php [Accessed: 13/11/14].

[70] Vuibau, T. Uni installs solar project. The Fiji Times Online. 11 Feb 2012. http://www.fijitimes.com/story.aspx?id=193104 [Accessed: 12/05/15].

[71] Taibi, E. June 2014. Islands: Light houses for the energy transition. IRENA. http://195.76.147.227/renforus/site/pdf/RENISLA2014/EmaluneleTaibiIRENA.pdf [Accessed: 11/11/14].

[72] Gonelevu, A. Mini and micro hydropower developments. http://www.hrcshp.org/en/world/db/fiji.pdf [Accessed: 11/11/14].

[73] Dornan M, Jotzo F. Electricity generation in Fiji: Assessing the impact of renewable technologies on costs and financial risks. Australian Agricultural and Resource Economics Society 55 ${ }^{\text {th }}$ Annual National Conference; 8-11 Feb. 2011. Melbourne. http://ageconsearch.umn.edu/bitstream/100544/2/Dornan.pdf [Accessed: 26/09/14].

[74] International Energy Agency. World energy outlook 2008. http://www.worldenergyoutlook.org/media/weowebsite/2008-1994/weo2008.pdf [Accessed: 26/09/14].

[75] Dornan M. Reform despite politics? The political economy of power sector reform in Fiji, 1996-2013. Energy Policy 2014; 67: 703-12.

[76] Fiji Electricity Authority. Tariff data. Personal Communication to Chand, D., Revenue Analyst on 30/09/14.

[77] Rao BB, Rao G. Structural breaks and energy efficiency in Fiji. Energy Policy 2009; 37: 3959-66.

[78] Organisation for Economic Co-Operation and Development, International Energy Agency. Energy statistics manual. France, OECD/IEA; 2004.

[79] Niles K, Lloyd B. Small Island developing states (SIDS) \& energy aid: Impacts on the energy sector in the Caribbean and Pacific. Energy for Sustainable Development 2013; 17: 521-30.

[80] Secretariat of the Pacific Community (SPC). External aid to Fiji. Personal Communication via email to Atishma Lal on 08/08/14.

[81] Sovacool BK. Expanding renewable energy access with pro-poor public private partnerships in developing world. Energy Strategy Reviews 2013; 1: 181-92. 
[82] Parthan B, Osterkorn M, Kennedy M, Hoskyns St. John, Bazilian M, Monga P. Lessons for low-carbon energy transition: Experience from the renewable energy and energy efficiency partnership (REEEP). Energy for Sustainable Development 2010; 14: 83-93.

[83] Agrawal A. Risk mitigation strategies for renewable energy project financing. Strategic Planning for Energy and the Environment 2012; 32(2): 9-20.

[84] Wulfinghoff DR. Where energy efficiency and alternative energy work, where they don't, and why. Strategic Planning for Energy and the Environment 2011; 31(2): 28-48.

[85] Vassileva I, Wallin F, Dahlquist E. Understanding energy consumption behavior for future demand response strategy development. Energy 2012; 46: 94-100.

[86] Fiji Revenue and Customs Authority. 2013 Incentives brochure: Fiji tax and customs incentives. $\quad$ http://www.frca.org.fj/wp-content/uploads/2012/10/2013-INCENTIVEBROCHURE-V2.pdf [Accessed: 13/08/14].

[87] Fiji Revenue and Customs Authority. Motor Vehicles. http://www.frca.org.fj/motorvehicles/ [Accessed: 13/08/14].

[88] Fiji Revenue and Customs Authority. Revenue measures introduced in the 2014 budget $\begin{array}{llllll}\text { address. } & \text { Public circular no. } 14 & \text { of } & 2013 .\end{array}$ http://fijilive.com/archive/showpdf.php?pdf=238.pdf [Accessed: 16/09/14]

[89] Fiji Commerce Commission. Final determination of electricity tariff rates: Fiji Electricity Authority. Date Issue 11 Dec 2012. http://www.commcomm.gov.fj/ [Accessed: 02/09/13].

[90] Fiji Commerce Commission. Independent power producing rates (IPP): Second phase: $\begin{array}{llll}\text { Full IPP } & \text { rates. }\end{array}$ http://www.fdoe.gov.fj/images/NEPReviewWorkPlan/ipp_final_authrztn_2nd_phase.pdf [Accessed: 22/09/14].

[91] Department of Energy. National energy policy 2006. Ministry of Energy and Mineral Resources. Fiji Islands.

[92] Fiji budget speech 2013. http://www.fiji.gov.fj/getattachment/873f98e2-b46f-4a0a-8a6a7e0b0b6f4279/Download-2013-Budget-Address-\%28pdf\%29.aspx [Accessed: 11/08/14]

[93] Republic of Fiji. Economic and fiscal update: Supplement to the 2013 budget address. Ministry of Finance, 22 November 2012. http://www.fiji.gov.fj/getattachment/6e106d3d2cb0-452f-8d39-dfc333f68af8/Download-2013-Budget-Supplement-\%28pdf\%29.aspx [Accessed: 11/08/14].

[94] IT Power. Review of existing subsidy and incentive schemes - Fiji. Final Report. 30 Sep, 2014. www.fdoe.gov.fi [Accessed: 29/04/2015].

[95] IT Power. Standardised power purchase agreement - Fiji. Draft Template. Feb, 2015. www.fdoe.gov.fj [Accessed: 29/04/2015]. 